\title{
The size, structure and efficiency of Mongolian flocks and herds on degraded grasslands
}

by Jargalsaihan, G., Gombosuren, U., Kemp, D.R., Behrendt, K., Lkhagvasuren, D., Gankhuyg, L. and Brown, C.G.

Copyright, publisher and additional information: This is the authors' accepted manuscript. The published version is available via Csiro.

Please refer to any applicable terms of use of the publisher

DOI link to the version of record on the publisher's site University 


\section{${ }^{\text {Int }}$ csio RANGELAND JOURNAL}

\section{Overgrazing and the size, structure and efficiency of Mongolian flocks and herds}

\begin{tabular}{|c|c|}
\hline Journal: & The Rangeland Journal \\
\hline Manuscript ID & RJ21014.R1 \\
\hline Manuscript Type: & Research paper \\
\hline $\begin{array}{r}\text { Date Submitted by the } \\
\text { Author: }\end{array}$ & 27-Aug-2021 \\
\hline Complete List of Authors: & $\begin{array}{l}\text { JARGALSAIHAN, Gantuya; Mongolian University of Life Sciences, } \\
\text { Research Institute for Animal Husbandry } \\
\text { Gombosuren, Udval; Mongolian University of Life Sciences, Research } \\
\text { Institute for Animal Husbandry } \\
\text { Kemp, David; Charles Sturt University, Graham Centre for Agricultural } \\
\text { Innovation } \\
\text { Behrendt, Karl; Harper Adams University, Land, Farm \& Agribusiness } \\
\text { Management; Charles Sturt University E H Graham Centre for } \\
\text { Agricultural Innovation, } \\
\text { LKHAGVASUREN, Davaasambuu; Mongolian University of Life Sciences, } \\
\text { Research Institute for Animal Husbandry } \\
\text { GANKHUYG, Luvsan; Mongolian University of Life Sciences, Research } \\
\text { Institute for Animal Husbandry } \\
\text { Brown, Colin; University of Queensland, School of Agriculture and Food } \\
\text { Sciences }\end{array}$ \\
\hline Keyword: & $\begin{array}{l}\text { Desert steppe, Grasslands, Grazing pressure, Native grasslands, } \\
\text { Rangeland management }\end{array}$ \\
\hline
\end{tabular}

\section{SCHOLARONE" Manuscripts}


 \\ The size, structure and efficiency of Mongolian}

\section{flocks and herds on degraded grasslands}

3 Gantuya JARGALSAIHAN 1, Udval GOMBOSUREN 1, David R KEMP A,2, Karl BEHRENDT 2,3,

4 Davaasambuu LKHAGVASUREN ${ }^{1}$, Luvsan GANKHUYG ${ }^{1}$, Colin G BROWN 4

5

$6{ }^{1}$ Research Institute for Animal Husbandry, Mongolian University of Life Sciences, Ulaanbaatar,

7 Mongolia

$8{ }^{2}$ Graham Centre for Agricultural Innovation, Charles Sturt University, Orange NSW 2800 Australia

$9{ }^{3}$ Land \& Agribusiness Department, Harper Adams University, Newport Shropshire TF10 8NB

10 England

${ }^{4}$ School of Agriculture \& Food Sciences, University of Queensland, St Lucia Queensland 4072

Australia

A Corresponding author. Email: dkemp@csu.edu.au

\section{SUMMARY}

Mongolia has seen a doubling in livestock numbers since 1990, which has resulted in significant grassland degradation, and accentuated the poor livestock productivity. This paper examines the size, structure and efficiency of Mongolian flocks and herds using a survey of herders in central Mongolia. The efficiency of livestock production is much lower than could be possible on these degraded grasslands. Ways of reducing animal numbers on the grassland and improving productivity are discussed. 


\section{ABSTRACT}

Since 1990 the number of livestock in Mongolia has more than doubled. In large areas of Mongolia, grassland degradation is now a problem of national concern. reducing the efficiency of livestock production and increasing environmental externalities. A survey was done of ten herders in two Soums (Altanbulag and Khashaat; heavily and moderately degraded, respectively) to measure the animals (sheep, goats, cattle \& horse numbers, sex and weights) and grasslands (species and biomass) every three months from April 2017 to December 2018. Rainfall is mostly in summer and mean monthly temperatures vary from -20 to $20^{\circ} \mathrm{C}$. Throughout the study the grassland herbage mass in summer was less than $0.5 \mathrm{t}$ dry matter/ha, below that considered sustainable for the steppe. Herders had 200-1000 sheep equivalents (SE $50 \mathrm{~kg}$ base weight), moved camps 2-4 times each year and stocking rates varied from 0.5-1 SE/ha. Female animals reached their mature weights by four years of age (sheep $50 \mathrm{~kg}$, goats $40 \mathrm{~kg}$, cattle $350 \mathrm{~kg}$, horses $300 \mathrm{~kg}$ ). Animals only grew over summer, but a significant part of that was compensatory gain in animals $>1$ year old. Over winter sheep and goats lost $21-29 \%$ of their liveweight, cattle and horses $15-30 \%$. The weaning rate was $43-48 \%$ across species. The male : female ratio ( $>2$ yrs old) was sheep $63 \%$, goats $72 \%$, cattle $27 \%$ and horses $106 \%$. All animals are managed in common mobs with no particular control of breeding. Areas where the efficiency of livestock production and grassland productivity could be improved are discussed.

Keywords: Mongolia, grasslands, degradation, livestock, efficiency 


\section{INTRODUCTION}

42 Grasslands and semi-arid grazing areas account for more than $80 \%$ of the land area in Mongolia, supporting almost 170,000 full time herder households (60\% of the total population, MONSIS 2019$)$.

The grasslands of Mongolia are both a cultural and economic issue of high priority for the Mongolian Government, as acknowledged in the 1992 Constitution. Herders in Mongolia can traditionally, graze where and when they desire as there is no land ownership or tenure. Grassland degradation in Mongolia is though of major concern, particularly within the central Aimags (Khishigbayar 2015, Densambuu et al. 2018) where more herders have moved to be closer to the capital Ulaanbaatar, to access better education, health services, job opportunities, and direct markets to consumers. Since 1990 there has been a doubling in the numbers of animals in Mongolia (Kemp, Han et al. 2020) leading to widely acknowledged degradation of the grasslands (Densambuu et al. 2018, Brown 2020). Government policies since 1990, encouraged herders to have more animals, assuming this would improve incomes. Achieving a sustainable balance in grassland use is now an aim of the Mongolian Government, though better mechanisms to do this are still being resolved (Wang, Fernandez-Gimenez 2012, Ulambayar et al. 2015a,b). Herders do recognise that there are too many animals on the grassland (Bruegger et al. 2014).

A reduction in animal numbers could be viable if it was accompanied with improvements in the efficiency of livestock production. Incomes would not suffer if the same output of animal product per household is achieved with fewer animals. Studies in Inner Mongolia, China, on the same grassland types and climate have shown that animal numbers per household can be reduced by up to $50 \%$, which improved grasslands without reducing net household income, when accompanied with improved feeding and shelter through winter, higher rates of fecundity and improved markets where payments favour the amount and quality of animal product per head ( $\mathrm{Li}$ et al. 2020). There is though very limited detailed information on the productivity of livestock in Mongolia to appraise what changes could be made. 
As background to the development of more efficient livestock production systems, this paper reports on case studies done on the flocks and herds of ten herders, across two of the acknowledged degraded Aimags in Central Mongolia. Additional data were recorded on current grassland condition. The general objective was to assess the efficiency of livestock production on the over-grazed, degraded grasslands. Aspects of the efficiency of current livestock production are then considered and options for improving productivity and the grasslands are discussed. The work presented here was an embedded case study (Yin 2003) designed also to describe the control conditions for models (Behrendt et al. 2020a,b) that are being used within a larger program to evaluate policy and management options (Brown 2020, Brown et al. 2021).

\section{METHODS}

This study was done on the steppe in Altanbulag Soum in Tuv Aimag and in Khashaat Soum in Arkhangai Aimag, provinces within central Mongolia (Fig. 1). Altanbulag Soum is $50 \mathrm{kms}$ south of the capital, Ulaanbaatar and Khashaat Soum $500 \mathrm{kms}$ to the west of Ulaanbaatar. These areas in central Mongolia are regarded as representative of the heavily to moderately degraded steppe grasslands, respectively (Densambuu et al. 2018). Moderately degraded grasslands are those where species number and the dominant edible species have declined. It is estimated they could though recover after 5-10 years of better management, whereas recovery in heavily degraded sites is more problematic and expensive to rectify. The steppe zone is $22 \%$ of Mongolia and among the more heavily utilised grasslands. In general, $60-70 \%$ of Mongolia's grasslands are regarded as degraded to some extent (Densambuu 2018). The steppe in Mongolia is the same grassland type as found across the typical and desert steppes in Inner Mongolia, China and is part of the vast Eurasian grasslands. Details on the herder's livestock, surveyed in each Soum, are given in Table 1. Data on the climate and Aimag livestock numbers were obtained from central Agencies (MONSIS \& Mongolian Meteorological Bureau). 
Fig. 1. Mongolia and location of sites used in this study: $1=$ Khashaat Soum, Arkhangai Aimag (3); $2=$ Altanbulag Soum, Tuv Aimag (6). The shaded areas are those considered more over-grazed.

Five herders were selected for these case studies in Altanbulag and five in Khaashat. They were selected in consultation with local officials and village leaders, to cover herders with a range from low to high animal numbers, who used different parts of each Soum, plus being willing to have their animals handled at intervals. Herders moved seasonally from two to four times each year (indicated by grazing areas in each season, Table 1). Animal liveweights, age, sex, and grassland biomass, were measured every three months from April 2017 (spring) through to December 2018 (winter). This was done on all animals in possession of each herder at each measurement (Table 1). Herders had from a small to large number of animals. Sites for measuring animal weights (using electronic scales and temporary facilities) changed as the herders moved, while grassland measurements were at fixed sites. Not all measurements went as planned due to various logistical problems e.g. severe winter conditions limit what can be done then, herders moved to different places to those expected where a measurement was not possible, and a local occurrence of foot and mouth disease resulted in one area being quarantined for several months.

All animals were ear tagged, a new practice in Mongolia. It was found that the Mongolian ear tags were lost from many animals and this limited the analysis of flock and herd structures over time, and only general average weights could be obtained, rather than following what each animal did. Data from the initial measurements did though enable the age and sex structure at that time to be analysed. All the livestock (sheep, goats, cattle and horses) in possession of the herder at each sampling time, were measured. This created a database of some 100,000 observations that was then summarised to show the general patterns in liveweight gain and loss through time, and flock and herd structures. Data was grouped into cohorts on age and sex. Each cohort was also estimated as a 50kg sheep 
equivalent (SE, i.e. divide their weight by 50 - adjustments for the physiological state of the animal were not feasible) to provide a common basis for comparison across livestock types and between herders. Additional estimates were made of the approximate seasonal grazing areas used by each herder's livestock.

Grassland biomass was recorded for each species within fixed quadrats located within the area the herder indicated they would be grazing, though this was not always successful as herders changed their plans based on grassland biomass and access across the landscape. Grassland measurements were done in areas judged to be 'average' by experienced research staff in discussions with the herders, for the intended grazing area. The quadrats used were $1 \mathrm{~m}^{2}$ with three replicates in 1 ha at each site. Plants were cut at ground level, sorted and oven dried. Sites were chosen as representative of the local landscape and at a similar intensity to the national survey (Densambuu et al. 2018). Traditional practice is for livestock to graze every day of the year. No shelter is provided for livestock in winter, apart from some windbreaks.

Two grazing experiments were done (one in each Soum) using small, fenced plots to assess how grazing, or resting at different times through the year, affected grassland composition and production, using a communal grazing design (Kemp \& Dowling 2000). Previous work in Inner Mongolia (Kemp 2020) had shown that early summer rests resulted in more grass growth over summer, while more intense grazing in winter resulted in severe reductions in growth during the following summer (Wang et al. 2020). These plots were located where herders said they would be grazing, but herders changed their grazing plans, which meant the experiment treatments did not proceed as planned. These plots though still provided some information on grassland productivity for comparison with measurements in the grazed areas. 


\section{RESULTS}

138

Fig. 2. Monthly temperatures and rainfall at Tuv and Arkhangai in 2017 and 2018. Triangles indicate when grasslands and animals were measured; dotted line shows zero temperature.

\section{Grassland condition}

The grassland data obtained from the areas being grazed by the ten households studied, showed the low levels of productivity in the two Aimags studied (Fig. 3). Grassland productivity does relate to rainfall patterns and in the years of this study there was less rainfall in early summer than late summer, even though the total was similar to the average. Less rain early in summer lessens total growth, but this often happens. Early summer rain is highly variable but is only greater than for late summer in $20-30 \%$ of the years. The data for $2017-18$ is a more typical pattern. However, the level of grassland growth in 2017-18 reflects the heavier grazing pressures in recent decades.

For a large part of the study period, the herbage mass was less than $0.5 \mathrm{t}$ dry matter per hectare, particularly in Altanbulag, the grassland in the more degraded state (Densambuu et al. 2018). This data is for the edible species (i.e. plants observed to be eaten, albeit some to a minor extent, as distinct from the species that animals did not touch) which were approximately $90 \%$ of the total herbage mass and includes grasses with variable fibre contents and semi-shrubs such as Artemisia 
161

162

163

164

165

166

167

168

169

170

171

172

173

174

175

176

177

178

spp. This reflects the moderate to heavy degradation state of the grasslands (Densambuu et al. 2018).

Fig. 3. Herbage mass in the grazed grasslands in the two study regions from 2016 to 2018. Data is from the areas being used by ten households. Codes as for herders as in Table 1.

\section{Aimag livestock numbers}

The trends in livestock numbers (as sheep equivalents since 1970) for Khashaat and Altanbulag (Fig. 4) show the rapid increase in livestock numbers since 1990, when regulations on livestock numbers were removed. The same pattern applies across Mongolia where animal numbers have doubled since 1990 (Kemp et al. 2020). The large declines in livestock numbers at various times are the years of dzuds (as indicated in Fig. 4), when massive livestock deaths have occurred (half the national flock/herd). MONSIS data indicates for adult sheep that mortality rates range on average, from $15-35 \%$ of the flock during dzuds, but $30-60 \%$ for young stock. This helps to explain the slow recovery time. Prior to 1990 more fodder was stored for feeding through winter, and while dzuds occurred the effects were much smaller than applied after 1990 (Fig. 4). In general, the main change in livestock species, has been the increasing numbers of sheep and goats compared to larger animals, which now comprise about half the livestock biomass, which in part reflects the declining grassland resource. The average stocking rates in SE/ha, since 1970 for each Aimag, have increased from 0.4 to 1.0 in Altanbulag and 1.2 to 2.0 in Khashaat, reflecting the higher average precipitation and better grassland condition in Khashaat.

Fig. 4. Total sheep equivalents for all livestock species in Khashaat and Altanbulag from 1970-2019

(adapted from MONSIS data). 


\section{Herder livestock numbers}

The average livestock numbers held by each herder over summer and winter during 2017/2018 are summarised in Table 1. The average flock/herd size in Khashaat was $15 \%$ less than in Altanbulag. Sheep and then goats were the largest groups, though one herder (K2) had a cattle herd about as large as their sheep flock. The total sheep equivalent held by herders varied from less than 200 to 1000. In conversations, herders and officials have commented that herders would like 1000 animals to be viable. Government policy also provided a reward to herders when they reached 1000 head.

In Khashaat three herders only used two grazing areas each year, another used three and the fifth had four grazing areas, as did all the herders in Altanbulag. The more frequent moves in Altanbulag probably reflect the poorer condition of the grassland. Herders used to move camps up to six times a year, but now they move less, in part because of the increasing numbers of herders and animals, limiting their options and because they wish to be near towns for services; education, health and jobs for family members. The total estimated average area used for grazing per herder was similar in Khashaat (4700ha) to Altanbulag (4900ha). While these grazing areas are extensive these herders did not have exclusive use as others would be travelling through or camping nearby and use some of the estimated grazing area. That means the actual stocking rate on the grassland would be higher than that estimated for individual herders. 


\section{Herder stocking rates}

During the survey period in 2017-18 there was decline in animal numbers and estimated stocking rates (Fig. 5) reflecting the poor grassland growth (Fig. 3) and a localised dzud winter in 2017-18, when there were above average snow falls and more animal deaths occurred. As noted above, these estimates of herder stocking rates are probably an under-estimate of the actual as other herders graze the same areas. It is also likely that herder estimates of grazing areas may be considerably in error. In Altanbulag Soum, where overall Aimag stocking rates among the surveyed herders were lower than in Khashaat Soum, the herders reduced their total SE by about $50 \%$ over the two years of the survey. In Khashaat the reduction was about 30\%, as these herders had lower stocking rates to start with. While the surveyed herders in Khashaat appeared to have lower stocking rates, it maybe that under common grazing there was more competition for the grasslands in that Aimag, which meant herders kept their animal numbers lower. As the total SE and land area in each Aimag were similar this suggests a similar overall stocking rate and the consequence that more animals from other herders grazed the land areas used by the surveyed herders in Khashaat than applied in Altanbulag. The short-term variation evident in these data reflects some trading of animals and that on each measurement day, herders may have had some animals located elsewhere.

Fig. 5. Average total sheep equivalents (sheep, goats, cattle \& horses) and average stocking rates for the herders surveyed in Khashaat and in Altanbulag from spring 2017 to winter 2018

\section{Animal growth rates with age}

Animal growth rates with age, were similar across the ten herders surveyed. To provide more detail the data from one herder are used where fewer ear tags were lost, allowing better analyses over time and where the numbers of females with or without young were recorded for sheep and goats. 
231 Ages are recorded as per Asian nomenclature; a one year old animal is in their first year after birth. 232 The following analyses apply to the data from spring, summer and autumn in 2017. Average livestock 233 numbers among the herders surveyed, declined after autumn 2017 (Fig. 5).

234 The Altanbulag herder (A5) had 457 sheep that were measured in 2017. Female sheep reached their mature liveweights at 3-4 years of age $(45-50 \mathrm{~kg})$ whereas the males exceeded female weights after 4 years of age then continued to increase in weight throughout their lives, reaching an average of $80 \mathrm{~kg}$ (Fig. 6). There were very few animals over six years of age. Three and four year old ewes with lambs were only $6 \%$ and $14 \%$ respectively, of all females. The five and six year old ewes with lambs comprised $54 \%$ of all females. This supports the view that in general female sheep were not mature until four years of age. Lambs were born in late winter, early spring (April) and by autumn 241 had reached an average weight of $35 \mathrm{~kg}$, a growth rate from birth of $\sim 180 \mathrm{~g} / \mathrm{d}$. Over summer (May to 242 September 2017) the average growth rate of all 1-2 and >3 year old sheep averaged 89 and 97 g/day, respectively.

Fig. 6. Sheep, goat, cattle and horse liveweights with age in autumn 2017, Altanbulag herder (A5). Peak annual liveweights were recorded in autumn, except for horses where more data was collected in spring.

There was a similar pattern with the 558 goats owned by this herder in 2017 (Fig. 6). The dry does increased in weight to $\sim 40 \mathrm{~kg}$, by four years of age. Males greater than three years old exceeded the 250 females in weight, averaging $\sim 50 \mathrm{~kg}$ at 4-5 years, and kept increasing to six years of age. There were 251 few males above five years of age. There were a few two and three year old does with kids, but they 252 were only $2 \%$ and $13 \%$ respectively, of all females. The four and five year old does with kids were $25327 \%$ and $20 \%$ of all does. There were only a few does older than five years. As with the sheep this 254 suggests most females were not mature until four years of age. Kids were on average $21 \mathrm{~kg}$ by 
autumn, a growth rate of $\sim 105 \mathrm{~g} / \mathrm{d}$ from birth. From spring to autumn 2017 , the average growth rates of 1-2 and $>3$ year old goats were 44 and 73 g/day on the grassland.

Female cattle were close to their mature weights $(\sim 380 \mathrm{~kg})$ by four years of age (Fig. 6$)$. There were 71 cattle in 2017. No specific data were available on which females had calves, but the general comment from herders was that few animals under four years of age had a calf. Males increased in weight throughout their life; $69 \%$ of the males were two years old, $6 \%$ were three years and $25 \%$ were four years. This indicates a high proportion of the cattle are sold as young males (2-3 years). Nine males were kept for breeding with the $\sim 25$ females over two years old i.e. a male ratio of $31 \%$. Calves in their first year grew at $\sim 550 \mathrm{~g} /$ day from birth until autumn 2017 . Over summer in 2017 the average growth rates of $1-2$ and $>3$ year old cattle were 290 and $430 \mathrm{~g} /$ day, respectively.

For the 14 horses of the Altanbulag herder (A5) the liveweights of the six females and eight males were near the maximum $(\sim 300 \mathrm{~kg})$ by five years of age (Fig. 6). Some of the younger male horses reached that weight at an earlier age, suggesting they may have received some extra fodder or been allowed more milk from their mothers. Horses are a dominant part of Mongolian culture and the slight excess of males over females probably reflects the retention of animals useful for racing. Horses are used for milk production, particularly to make airag, fermented mares' milk ( $2 \%$ alcohol, preserved to then be useful throughout the year). No data was obtained on foals in their first year, but 2 year old horses grew at $\sim 90 \mathrm{~g} / \mathrm{day}$ over summer and 3-4 year olds at $340 \mathrm{~g} / \mathrm{day}$.

In general people in Mongolia prefer to buy sheep and goats for consumption when 3-4 years old i.e. when reaching maximum weights. Cattle can be consumed at an earlier age, depending upon consumer needs. Storing meat in summer can be problematic and hence smaller animals are more appropriate. 


\section{Animal liveweight losses over winter}

Each year in Mongolia and IMAR, severe winter conditions result in substantial weight loss of all animals, irrespective of the grassland growth over summer. For mature animals this often means that the maximum liveweights at the end of summer, early autumn are similar to what they were a year before. Much of the growth through summer, for mature animals, is simply regaining the liveweight lost through winter i.e. compensatory gain. There is a very strong relationship between liveweights in autumn, early winter and liveweights in the following spring as shown by the data for Altanbulag (Fig. 7); similar data were found for Khashaat. The rate of change in liveweight, in spring averaged $0.6 \mathrm{~kg}$ for each $\mathrm{kg}$ the previous autumn, for small animals and $0.56 \mathrm{~kg}$ for larger animals (i.e. the slopes of fitted regressions; no significant difference between groups). This meant that 30 and $50 \mathrm{~kg}$ small animals lost on average, $21 \%$ and $29 \%$ respectively in absolute terms of their liveweight over winter, while 200 and $400 \mathrm{~kg}$ large animals lost $15 \%$ or $30 \%$ respectively of their liveweight. These rates of loss are similar to other, unpublished data in Mongolia and in Inner Mongolia and the Qinghai-Tibetan Plateau in China, and in Central Asia. The herder surveys did find that individual animals lost up to $50 \%$ of their bodyweight, a result predicted by modelling based on relationships in the literature (Behrendt et al. 2020a).

Fig. 7. Relationship between liveweights in autumn 2017 (late September or early December) and liveweight in spring 2018 (late April) for sheep and goats, and cattle and horses for the five herder households in Altanbulag. Only four herders had cattle and horses.

\section{Animal reproductive rates}

To estimate the reproductive rates of flocks and herds the data from spring, summer and autumn 2017 measurements were used. While some 2 year old animals did produce young, the higher 
302

303

304

305

reproductive rates were in animals over three years old. As it is known that 2-3 year old animals in other countries can be reproductive when well managed, the breeding population was defined as animals greater than 2 years of age.

For the Altanbulag (A5) herder example considered here, there were 261 female and 195 male sheep; 197 of the females and 64 of the males were greater than 2 years old (i.e. potential breeders) leaving 99 females and 159 males that were 1-2 years old. As the two year old sheep were only just into that cohort when measurements were taken and few if any lambs are sold before autumn in their second year, this meant over two years (2016-17) there had been at least 258 lambs born i.e. 129 per year, from the 197 mature females; a minimum weaning percentage of $65 \%$. Twins are rare. It was evident that more young male sheep had been sold than female, keeping $\sim 20$ mature males per year from each cohort, but retaining a male : female ratio (> 2 years old) of $32 \%$.

The goat flock had 363 females and 195 males; with 240 females and 112 males greater than 2 years old, leaving 123 females and 98 males 1-2 years old; 111 kids per year were then weaned from the 240 females i.e. $46 \%$. Under stressful conditions as occur each winter in Mongolia, goats are known to abort more foetuses than sheep. The male : female ratio for goats $>2$ years old was $47 \%$. This higher male ratio than for sheep could reflect the higher value of cashmere than wool produced by the males.

The pooled data across the ten herders surveyed showed that the estimated average weaning percentages in $2016-17$ varied from $43 \%$ for horses, to $46 \%$ for goats and cattle to $48 \%$ for sheep (Table 2). Essentially this meant that for the potential breeding population, females were only producing young, every second year. There were a high proportion of males capable of breeding, for each category of livestock. This indicates little, if any, control of breeding. It is also likely that inbreeding is common. The Mongolian recommendations are for one male to $30-40$ females across 

species, but it seems unlikely that happens. Mongolian flocks and herds are not managed as breeding and, or production groups.

The national data for Mongolia recorded that in 2019 (MONSIS 2019) there were $31 \mathrm{~m}$ females used for breeding and $17 \mathrm{~m}$ mature males (all species) i.e. a male : female ratio of $56 \%$. These general values are similar to that estimated for individual herders (Table 2). The statistics though suggest that only $0.56 \mathrm{~m}$ males were used for breeding (i.e. $2 \%$ ) but that needs to be questioned as flocks and herds are not separated into groups and male castration does not seem to be common. Recommendations from livestock experts are that the breeding male : female ratio should be (about) $1.5-4 \%$ for sheep, goats and camels, $3 \%$ for cattle and $10 \%$ for horses. These are realistic recommendations, but it is not evident that herders apply them.

Table 2. Average numbers of livestock, weaning rates and percent males for the ten herders surveyed in Khashaat and Altanbulag Soums. Data are for the maximum number recorded in a spring, summer or autumn 2017 measurement. The totals include animals whose age not recorded.

\section{Mongolian sheep indices}

341 The data collected from herders enabled a check on the common ratios used in Mongolia to estimate 342 sheep head indices/equivalents (Table 3). Sheep Head Indices are a simplified version of the Dry 343 Sheep Equivalent used in Australia, but without any adjustments for the physiological state of the 344 animals. This information is useful for refining estimates of actual grazing pressures on the 345 grasslands and for refining relative impacts of different livestock species. The data collected in the 346 herder surveys reported here (using the eight measurement periods over 2017-18 data) shows that 347 the average sheep was $35-45 \mathrm{~kg}$ and other species were generally smaller than the common ratios 
would imply e.g. on average, cattle were $250 \mathrm{~kg}$ or less, and horses less than $300 \mathrm{~kg}$. The Mongolian

Sheep Head index is then approximately a $40 \mathrm{~kg}$ animal.

The larger sheep equivalent values, calculated from the data obtained in this study, are for summer and the smaller ones for winter. The summer values are more important as they define the reference weight for animals in modelling (Behrendt et al. 2020a) which is more useful for estimating consumption rates of grassland. No data were obtained on the weights of Bactrian camels. However, given the Sheep Head indices for other species were greater than the standard $50 \mathrm{~kg}$ Sheep Equivalents, it may be that the camel sheep equivalent may only be about 4 i.e. $\sim 200 \mathrm{~kg}$ liveweight. While this data does suggest that the index values used in Mongolia are a bit optimistic, that may not be a problem as the index values provide a small buffer when estimating forage consumption rates and grazing pressures.

Table 3. Mongolian Sheep Head Indices, compared to the mean range in 50kg Sheep Equivalents (SE) from

\section{DISCUSSION}

364 The 1992 Mongolian Constitution states that livestock are the national wealth of the country and subject to State protection. Various formal institutions are designed to protect the social and economic values of the grasslands (Brown 2020). Yet since 1990 the Government has sought to increase herder incomes by encouraging increased animal numbers (Fig. 4, Kemp et al. 2020) which devising strategies that can improve grasslands and incomes. These twin problems can be solved if ways are found to reduce livestock numbers on the Mongolian grasslands while also maintaining or

371 increasing herder incomes. 
372 The analysis presented here of the Mongolian flock and herd structures, in liveweights with age and 373 season, growth and reproductive rates all show slow animal growth rates and limited numbers of 374 new animals for household use, sale or trading each year, a consequence of the low productivity of 375 these degraded grasslands and the harsh climatic conditions in winter. These inefficiencies mean 376 that herders keep as many animals as they can to try and improve their incomes. Mongolian herders 377 are among the poorest people in the country with incomes close to or below the poverty line. The 378 results presented here characterise herders as 'keepers' of livestock rather than 'producers' or 379 'breeders' (Neidhardt et al. 1996, Kemp \& Michalk 2011b). Animals are kept but there is very limited 380 feeding through the nine months of below zero temperatures, very limited shelter and breeding is 381 not really managed. The skill of herders lies in their considerable ability to manage the survival of 382 animals under these tough conditions, rather than a focus on production of saleable products.

383 The two sites studied in this work are in grassland areas characterised as moderately (Khashaat) or 384 heavily (Altanbulag) degraded (Densambuu et al. 2018). Those general descriptions were supported 385 by the limited grassland measurements taken (Fig. 3). While some differences in grassland growth 386 were evident, there weren't any significant differences in the livestock productivity between sites. 387 The forage supply from grasslands over summer did enable animal growth, but in mature animals a 388 large part of that was simply regaining the weight lost through winter. Research in Inner Mongolia, 389 China on the same grassland type (Wang et al. 2020, Zhang et al. 2020) found that grazing needs 390 to maintain the herbage mass above $0.5 \mathrm{t}$ dry matter per hectare to maintain, or increase, the more 391 useful species and animal growth rates. Data from ungrazed fenced plots (not presented) showed 392 that under the seasonal conditions of this study the grassland took two years for the accumulated 393 herbage mass to exceed the threshold of $0.5 \mathrm{t}$ dry matter per hectare in each Aimag. The grassland 394 studies done in Inner Mongolia also found that the optimal utilisation rate for the desert and typical 395 steppe was 20 and 40\%, respectively (Wang et al. 2020, Zhang et al. 2020); utilisation being 396 measured as the difference between inside and outside cages of which about half is the estimated 
consumption by livestock (Badgery et al., 2020). Estimates for Mongolia, using remote sensing, indicate a utilisation rate of over $70 \%$ in many areas (Gao et al. 2015). Clearly, degradation of the grasslands and low animal productivity over summer are due to overgrazing. In winter grasslands are well below maintenance requirements leading to the large weight loss recorded. Very little stored fodder is available to alleviate that weight loss. While the sites studied are considered degraded, anecdotally it is considered that similar problems exist across Mongolia. This is because even where grasslands are more productive, herders have moved to those areas thinking they can then feed their animals better, but they are now being over-stocked. In addition, even the more productive grasslands still only provide green fodder for 3-5 months each year. The rest of the year the only forage available is of low quantity and quality, and cold conditions mean that animals will only lose weight (Behrendt et al. 2020a).

How then can the grasslands be rehabilitated without adversely affecting herder livelihoods? A key part is to improve the efficiencies of livestock production, culling the least productive animals and improving management of the better ones. This would require a multi-faceted approach. Within the flocks and herds studied, it is evident that growth rates are low e.g. lambs are into their second year before being of suitable size for marketing. Females are on average, only producing a lamb, kid, calf, or foal every second year. This reflects poor nutrition and lack of adequate shelter through winter (Wu et al. 2020). Research and demonstrations in China (Kemp 2020) where many of the grasslands would be characterised as heavily degraded, have shown that culling unproductive animals does not reduce household incomes and over time flock/herd productivity improves. A 50\% reduction in animals can be viable ( $\mathrm{Li}$ et al. 2020) and the consequent reduction in stocking rates enables improvement in grassland condition as well as doubling the available fodder per head in these feed limited systems. The gains in China came also from using warm sheds in winter, that in effect replaced some of the lack of fodder and reduced weight loss (Wu et al. 2020). 
421 Prior to 1990 in Mongolia, apart from maintaining lower livestock numbers, there were national 422 programs to conserve hay for winter feed, which meant fluctuations in the national flock/herd were 423 small (Fig. 4) and dzuds had less impact. Government support would though be needed at present, 424 to conserve the quantities of fodder required to eliminate the need for animals to graze the 425 grasslands throughout winter, and to be kept in a warmer environment. Herders do construct rough 426 permanent windbreak shelters for use in winter and these could be considerably improved. The need 427 to improve the fodder supply has been long recognised by the Mongolian government, though the 428 emphasis recently has mostly been on reserves to mitigate the extreme effects of dzuds, rather than 429 for regular use (Gunjal et al. 2014, Fernandez-Gimenez et al. 2015). The State Emergency Fodder 430 Fund in 1990/91 supplied 200kt of fodder to herders, but only 18kt in 1994/95 (Asian Development 431 Bank 1995). The Fund was disbanded in 1996 on advice from the Asian Development Bank that 432 transportation costs exceeded the feeding value. By 2011 fodder production was only 6 per cent of 4331989 levels (Rasmussen and Dorlig 2011). Ad hoc fodder subsidies are employed on occasion with 434 Addison (2012) noting that Soum governments subsidised fodder during the 2010 dzud to a level of about $50 \%$, making prices on par with those in a good year. Nevertheless, both subsidised and commercial fodder are still generally in short supply.

437 The government has instigated other initiatives to increase the quantity and type of hay and fodder 438 available to the livestock industry. The Livestock Fodder Program ( $3 \%$ of the national budget) 439 included support for enterprises and herders with funding for small tractors with hay and feed 440 equipment (50 per cent subsidisation) and for small and medium sized hay and fodder producing 441 enterprises (Rasmussen and Dorlig 2011). Funding was also made available for fencing hay fields. 442 After the $2000 / 2001$ dzuds, the system of national reserves was re-established whereby Aimags and 443 Soums were directed to establish additional local reserves. There are now Soum, Aimag and national 444 strategic reserves for feed and fodder, although no budget for the Soum reserves. Aimag reserves 445 are established under the Ministry of Food, Agriculture and Light Industry with procurement 
supported by state and local budgets. Fodder storage facilities though remain in poor condition

447 (Rasmussen and Dorlig 2011). A more concerted effort is clearly needed to improve fodder 448 production, quality and use, to help herders move from survival to production, particularly to reduce 449 weight loss through pregnancy in winter. This will require improving the productivity of fewer animals 450 to reduce stocking rates so that more forage is available per animal. Reduced grazing pressures on 451 the grasslands would enable higher plant and thence animal growth rates on those grasslands and a gradual increase in herbage mass.

The whole of Mongolia is open to common grazing, where herders are not restricted in where they can graze. This means that some form of collective agreement is needed among herders as to when and where to graze, and ultimately the numbers of animals that can be grazed. In practice herders tend to stay within an area similar to the Aimag boundaries (Densambuu, personal communication). Various attempts are being made to establish Pasture User Groups (PUGs) to self-manage the grasslands. The Swiss Development Corporation developed the "Green Gold” program (SDC 2015) with the Mongolian Government. This involves mapping of the grasslands, then supporting local herders to make better decisions about what to graze and when. Herders from outside the area can are improving where PUGs have formed (Ulambayar et al. 2015a). To date these programs have not included an emphasis on reducing animal numbers, except by limiting the herders from outside the PUG areas who graze the groups grassland. Reducing animal numbers is not a simple task unless local demonstrations can show the benefits (Kemp 2020, Li et al. 2020). Surveys in Inner Mongolia found that Mongolian herders there did acknowledge the grasslands were overgrazed yet the intention of some was to increase their number of animals Hou et al. 2020). This increase reflected their view, under current management practices, of the number of animals they needed to provide for their household and also to maintain their status as a herder. 
470 Animal numbers could be directly regulated through various mechanisms $e . g$. by charging a grazing

471 fee for animals and, or a livestock tax (Brown 2020), and the wider use of Pasture User Groups 472 (Ykhanbai et al. 2004, Addison et al. 2013, Fernandez-Gimenez et al. 2015, Densambuu et al. 2018) 473 where local communities regulate who and where animals graze, and Payments for Environmental 474 Services (PES), which require a reduction in animal numbers (Brown 2020). But simply limiting 475 animal numbers without the adoption of strategies to improve animal efficiencies could result in 476 reduced incomes for the herders who are among the poorest people in Mongolia.

\section{ACKNOWLEDGMENTS}

479 The Australian Centre for Agricultural Research funded this work as part of a program to identify 480 effective methods for improving grassland environmental services (Brown 2020). Additional support 481 came from the Research Institute for Animal Husbandry, Mongolian University of Life Sciences. We 482 especially thank the herders and officials in the Ministry of Food, Agriculture and Light Industry for 483 their continuing support and interest in resolving this national problem.

485 The authors declare they have no conflicts of interest.

486 Data collected and analysed for this paper is unavailable

\section{REFERENCES}

Addison J. (2012). Institutional settings, herder livelihoods and rangeland condition in the Gobi Desert, PhD thesis, St Lucia: The University of Queensland.

491 Addison J, Davies J, Friedel M, Brown C. (2013). Do pasture user groups lead to improved rangeland 492 condition in the Mongolian Gobi Desert? Journal of Arid Environments 94: 37-46. 
Asian Development Bank (1995). Report and Recommendation of the President to the Board of Directors on a proposed lean and technical assistance grant to Mongolia for the Agriculture Sector Program. RPP: MON 27536, Ulaanbaatar: Asian Development Bank.

Badgery W, Kemp D, Zhang YJ, Wang ZW, Han GD, Sun Y, Hou FJ, Michalk D, Behrendt K. (2020). Devising sustainable grasslands grazing management practices for the future of Chinese grasslands. In Kemp DR (ed) Sustainable Chinese Grasslands. Australian Centre for International Agricultural Research, Monograph 210 ISBN 978-1-922345-21-9 (print) ISBN 978-1-922345-20-2 (online) ISSN 10318194 (print) ISSN 1447-090X (online) Chapter 10, 191-210.

Behrendt K, Liu HB, Kemp D, Takahashi T. (2020a). Sustainability modelling of grassland systems. In Kemp DR (ed) Sustainable Chinese Grasslands. Australian Centre for International Agricultural Research, Monograph 210 ISBN 978-1-922345-21-9 (print) ISBN 978-1-922345-20-2 (online) ISSN 1031-8194 (print) ISSN 1447-090X (online) Chapter 6, 97-124.

Behrendt K, Liu H, Takahashi T, Kemp DR. (2020b). StageTHREE Sustainable Grassland Model (v1.07) Model description and users guide. ACIAR, Revised February 2020, pp 69.

Brown CG. (2020). (Ed) Common Grasslands in Asia: A Comparative Analysis of Chinese and Mongolian Grasslands, Cheltenham, UK, Edward Elgar Publishing. pp 181.

Brown CG, Behrendt K, Li P, Qiao G, Bennett J, Bao Z, Addison, J, Kemp DR, Han GD, Zhang J. (2021). Revising China's grassland policies: an interdisciplinary and ex-ante analysis. The Rangeland Journal. 42(6), 435-445. https://doi.org/10.1071/RJ20097

Bruegger RA, Jigjsuren O, Fernandez-Gimenez ME. (2014). Herder Observations of Rangeland Change in Mongolia: Indicators, Causes, and Application to Community-Based Management. Rangeland Ecology \& Management 67, 119-131. DOI: 10.2111/REM-D-13-00124.1

Densambuu B, Sainnemekh S, Bestelmeyer B, Budbaatar U. (2018). National Report on the Rangeland Health of Mongolia: Second Assessment, Ulaanbaatar: Green Gold - Animal Health Project, Swiss Development Corporation. 
518 Fernandez-Gimenez M, Batkhishig B, Batabuyan B, Ulambayar T. (2015). Lessons from the dzud:

519 community-based rangeland management increases the adaptive capacity of Mongolian herders to winter disasters, World Development, 68, 48-65.

521 Gao W, Angerer JP, Fernandez-Gimenez ME, Reid RS. (2015) Is Overgrazing A Pervasive Problem Across Mongolia? An Examination of Livestock Forage Demand and Forage Availability from 2000 to 2014. Proceedings of the Trans-disciplinary Research Conference: Building Resilience of Mongolian Rangelands, Ulaanbaatar Mongolia, June 9-10, 2015, 35-41.

Gunjal K, Annor-Frembpong A. (2014). Review, estimation and analysis of agricultural subsidies in Mongolia, report by the World Bank to the Mongolian Ministry of Industry and Agriculture, accessed 18 April 2019 at http://documents.worldbank.org/curated/en/985931468197057985/pdf/101086-WP-P130366-PUBLICBox393257B-Review-Estimation-and-Analysis-of-Agricultural-Subsidies-in-Mongolia.pdf.

Hou XY, Yin YT, Kemp DR, Li P. (2020). Herders attitudes on stocking rates and implications for grassland management in northern China. In Kemp DR (ed) Sustainable Chinese Grasslands. Australian Centre for International Agricultural Research, Monograph 210 ISBN 978-1-922345-21-9 (print) ISBN 978-1-92234520-2 (online) ISSN 1031-8194 (print) ISSN 1447-090X (online) Chapter 5, 81-96.

Kemp DR. (ed). (2020). Sustainable Chinese Grasslands. Australian Centre for International Agricultural

Kemp DR, Dowling PM. (2000). Towards sustainable temperate perennial pastures. Australian Journal of Experimental Agriculture 40, 125-132.

538 Kemp DR, Michalk DL. (Eds). (2011a). Sustainable Development of Livestock Systems on Grasslands in $539 \quad$ North-Western China. ACIAR Proceedings 134. pp 189.

540 Kemp DR, Michalk DL. (2011b). Livestock production styles and managing grassland ecosystems. in: G 541 Lemaire, J Hodgson, Abad Chabbi. (Eds). Grassland Ecosystems: Productivity and Environmental 542 Issues. Chapter 1.6 Published by CABI. p 53-62. 
543 Kemp DR, Han G, Li P, Wang Z, Zhao M, Udval G, Gantuya J, Zhang Y, Hou X, Addison J. (2020).

544 Grassland Livestock Systems. Chapter 3 in C.G. Brown (Ed) Common Grasslands in Asia: A

545 Comparative Analysis of Chinese and Mongolian Grasslands, Cheltenham, UK, Edward Elgar Publishing.

546 Khishigbayar J, Fernandez-Gimenez ME, Angerer JP, Reid RS, Chantsallkham J, Baasandorj Y,

547 Zumberelmaa D. (2015). Mongolian rangelands at a tipping point? Biomass and cover are stable but

548 composition shifts and richness declines after 20 years of grazing and increasing temperatures. Journal 549 of Arid Environments 115, 100-112.

550 Li ZG, Han GD, Zhao ML, Kemp D, Wang ZW, Yuan Q, Li JW, Wang RZ, Wilkes A, Wang J. (2020). Farm

551 demonstrations: what we are learning? In Kemp DR (ed) Sustainable Chinese Grasslands. Australian

552 Centre for International Agricultural Research, Monograph 210 ISBN 978-1-922345-21-9 (print) ISBN

553 978-1-922345-20-2 (online) ISSN 1031-8194 (print) ISSN 1447-090X (online) Chapter 4, 57-80.

554 MONSIS (Mongolian Statistical Information Service) (2019), MONSIS Database, Mongolia National Statistics $555 \quad$ Office, accessed May 2019 at www.1212.mn.

556 Neidhardt R, Grell H, Schrecke W, Jakob H. (1996). Sustainable livestock farming in east Africa. Animal $557 \quad$ Research \& Development 43/44: 45-53.

558 Rasmussen D, Dorlig S. (2011). Mongolia - Improving Feed and Fodder Supply for Dzud Management, 559 Washington, D.C.: World Bank, accessed May 2019 at

560 http://documents.worldbank.org/curated/en/158631468274239063/Mongolia-Improving-feed-and-fodder$561 \quad$ supply-for-dzud-management.

562 SDC (Swiss Agency for Development and Cooperation) (2015). National Report on the Rangeland Health of $563 \quad$ Mongolia. Green Gold Project Report.

564 Ulambayar T, Fernandez-Gimenez M, Batjav B, Baival B, (2015a). What Matters Most in Institutional Design 565 for Community-Based Rangeland Management in Mongolia? Proceedings of the Trans-disciplinary 566 Research Conference: Building Resilience of Mongolian Rangelands, Ulaanbaatar Mongolia, June 9-10, $567 \quad 2015,107-111$. 
568 Ulambayar T, Fernandez-Gimenez M, Batjav B, Baival B. (2015b). What Explains Positive Social Outcomes 569 of Community-Based Rangeland Management in Mongolia? Proceedings of the Trans-disciplinary 570 Research Conference: Building Resilience of Mongolian Rangelands, Ulaanbaatar Mongolia, June 9-10, $2015,115-120$.

Wang XY, Fernandez-Gimenez ME. (2012). The Market, the State and the Environment: Implications for Community-Based Rangeland Management. Chapter 11 (eds M.E. Fernandez-Gimenez et al.) Restoring Community Connections to the Land. CAB International 2012. 209-217.

Wu JP, Gong XY, Lang X, Kemp D, Takahashi T, Michalk D, Hou XY, Zhang XQ. (2020). Changing animal

Yin RK. (2003). Case study research, design and methods. $3^{\text {rd }}$ Edn Newbury Park, Sage Publications ISBN 0-7619-2553-6

Ykhanbai H, Bulgan E, Beket U, Vernooy R, Graham J. (2004). Reversing grassland degradation and improving herders' livelihoods in the Altai mountains of Mongolia. Mountain Research and Development, 24(2): 96-100. DOI: http://dx.doi.org/10.1659/0276-4741(2004)024[0096:RGDAlH]2.0.CO;2 steppe. In Kemp DR (ed) Sustainable Chinese Grasslands. Australian Centre for International Agricultural

Table 1. Mean livestock numbers over summer and winter in $2017 / 2018$ for the ten herders surveyed and total sheep equivalents (SE) and estimated grazing area in each season. 
595 Table 2. Average numbers of livestock, weaning rates and percent males for the ten herders 596 surveyed in Khashaat and Altanbulag Soums. Data are for the maximum number recorded in a 597 spring, summer or autumn 2017 measurement. The totals include animals whose age are not 598 recorded.

599 Table 3. Mongolian Sheep Head Indices, compared to the mean range in 50kg Sheep Equivalents (SE) 600 from animal weights.

601 
602 Table 1. Mean livestock numbers over summer and winter in 2017/2018 for the ten herders surveyed

603 and total sheep equivalents (SE) and estimated grazing area in each season.

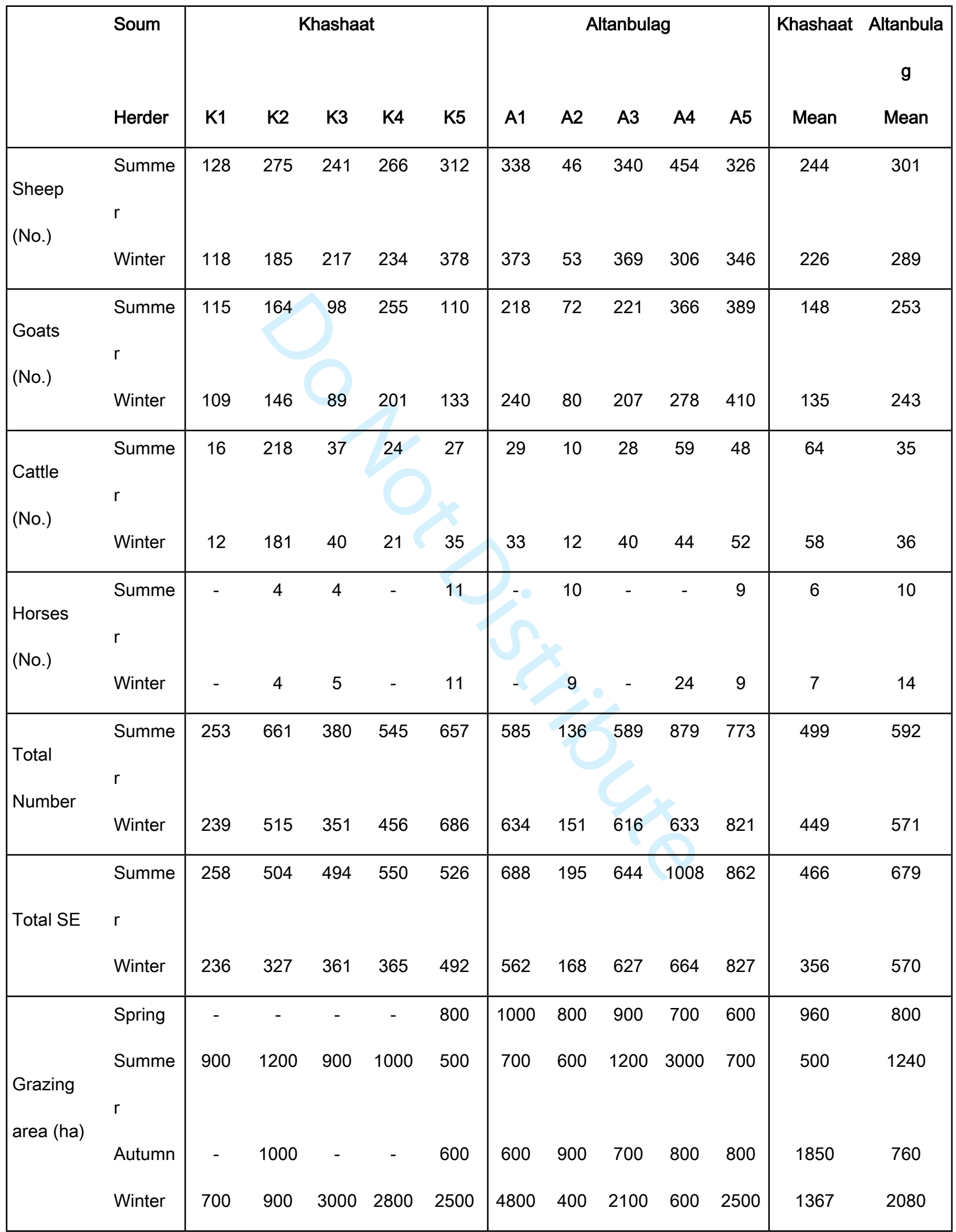


606 Table 2. Average numbers of livestock, weaning rates and percent males for the ten herders 607 surveyed in Khashaat and Altanbulag Soums. Data are for the maximum number recorded in a 608 spring, summer or autumn 2017 measurement. The totals include animals whose age are not 609 recorded.

610

\begin{tabular}{|c|c|c|c|c|c|c|c|c|c|}
\hline \multirow{2}{*}{$\begin{array}{c}\text { livestoc } \\
k\end{array}$} & \multicolumn{3}{|c|}{ females } & \multicolumn{3}{|c|}{ males } & \multirow{2}{*}{$\begin{array}{l}\text { young } \\
\text { / year }\end{array}$} & \multirow{2}{*}{$\begin{array}{c}\text { weanin } \\
\text { g } \\
\%\end{array}$} & male : \\
\hline & & & tota & $\begin{array}{l}1-2 \\
y r s\end{array}$ & $\begin{array}{l}>2 \\
\text { yrs }\end{array}$ & total & & & $\begin{array}{l}\%> \\
2 y r s\end{array}$ \\
\hline sheep & 50 & 115 & 184 & 59 & 73 & 139 & 55 & $48 \%$ & $63 \%$ \\
\hline goats & 41 & 79 & 133 & 32 & 57 & 102 & 37 & $46 \%$ & $72 \%$ \\
\hline cattle & 11 & 23 & 32 & 10 & 6 & 15 & 10 & $46 \%$ & $27 \%$ \\
\hline horses & 2 & 5 & 8 & 2 & 6 & 9 & 2 & $43 \%$ & $106 \%$ \\
\hline
\end{tabular}


612 Table 3. Mongolian Sheep Head Indices, compared to the mean range in 50kg Sheep Equivalents 613 (SE) from animal weights.

\begin{tabular}{|l|c|c|}
\hline Livestock & $\begin{array}{c}\text { Sheep } \\
\text { Head Index }\end{array}$ & $\begin{array}{c}\text { Sheep Equivalent } \\
\mathbf{( 5 0 k g )}\end{array}$ \\
\hline Sheep & 1 & $0.7-0.9$ \\
Goat & 0.9 & $0.6-0.8$ \\
Cattle & 6 & $3.9-5.2$ \\
Horse & 7 & $4.4-6.1$ \\
Camel & 5 & \\
\hline
\end{tabular}

614 


\section{Figures}

616 Fig. 1. Mongolia and location of sites used in this study: 1 = Khashaat Soum, Arkhangai Aimag (3);

6172 = Altanbulag Soum, Tuv Aimag (6). The shaded areas are those considered more over-grazed.

618 Fig. 2. Monthly temperatures and rainfall at Tuv and Arkhangai in 2017 and 2018. Triangles indicate 619 when grasslands and animals were measured; dotted line shows zero temperature.

620 Fig. 3. Herbage mass in the grazed grasslands in the two study regions from 2016 to 2018. Data is 621 from the areas being used by ten households. Herder codes as per Table 1. Desirable species are 622 those that animals may eat a little or a lot of.

623 Fig. 4. Total sheep equivalents for all livestock species in Khashaat and Altanbulag from 1970-2019 624 (adapted from MONSIS data). Dzuds occurred in 1977, 1983 \& 1985, 2000-2001 \& 2010.

625 Fig. 5. Average total sheep equivalents (sheep, goats, cattle \& horses) and average stocking rates 626 for the herders surveyed in Khashaat and in Altanbulag from spring 2017 to winter 2018.

627 Fig. 6. Sheep, goat, cattle and horse liveweights with age in autumn 2017, Altanbulag herder (Lk). 628 Peak annual liveweights were recorded in autumn, except for horses where more data was collected 629 in spring.

630 Fig. 7. Relationship between liveweights in autumn 2017 (late September or early December) and 631 liveweight in spring 2018 (late April) for sheep \& goats, and cattle \& horses for the five herder 632 households in Altanbulag. Only four had cattle and horses. 
634 Fig. 1. Mongolia and location of sites used in this study: 1 = Khashaat Soum, Arkhangai Aimag (3);

6352 = Altanbulag Soum, Tuv Aimag (6). The shaded areas are those considered more over-grazed.

636

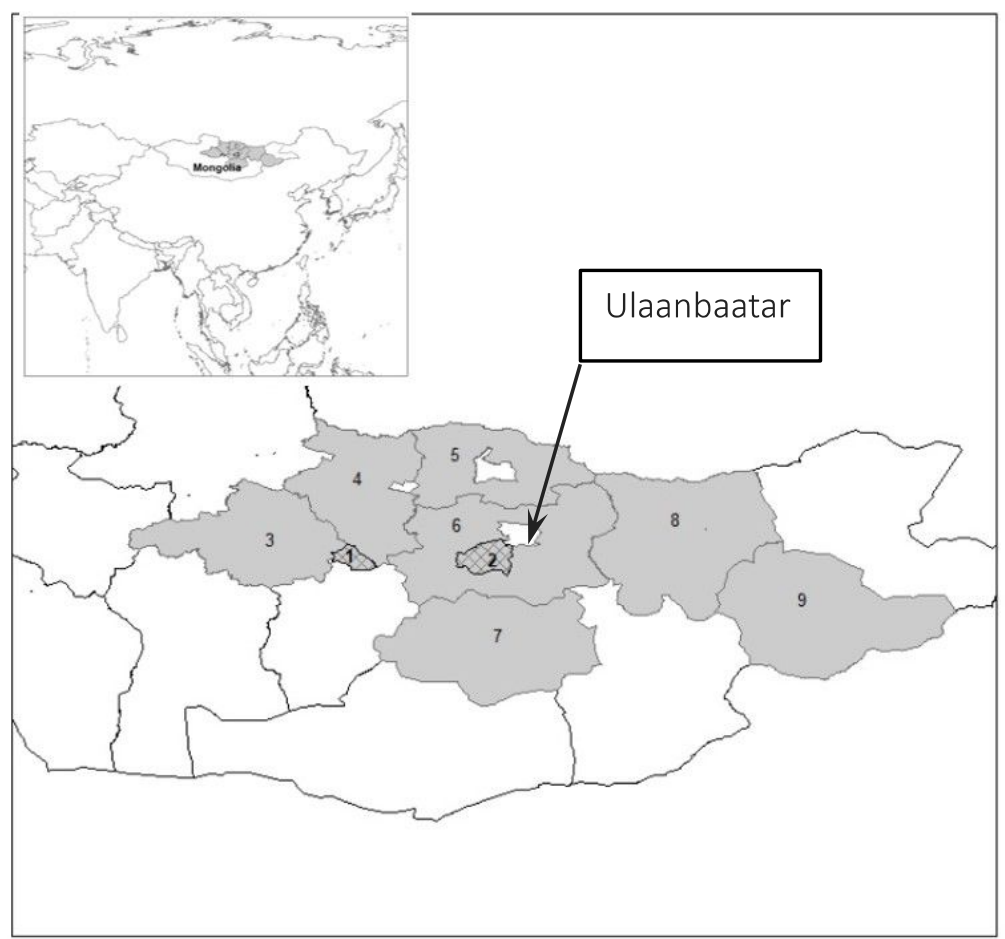

637

638 
639 Fig. 2. Monthly temperatures and rainfall at Tuv and Arkhangai in 2017 and 2018. Triangles indicate 640 when grasslands and animals were measured; dotted line shows zero temperature.

641

642

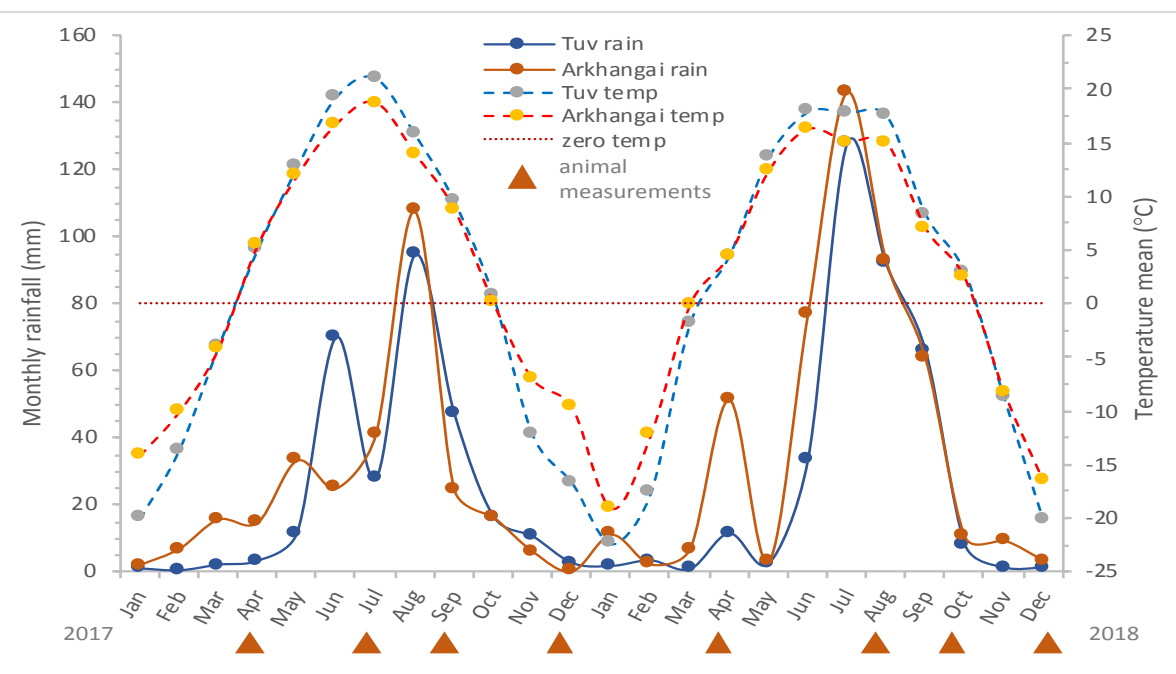

643 
644 Fig. 3. Herbage mass in the grazed grasslands in the two study regions from 2016 to 2018. Data is 645 from the areas being used by ten households. Herder codes as per Table 1. Desirable species are 646 those that animals may eat a little or a lot of.

647
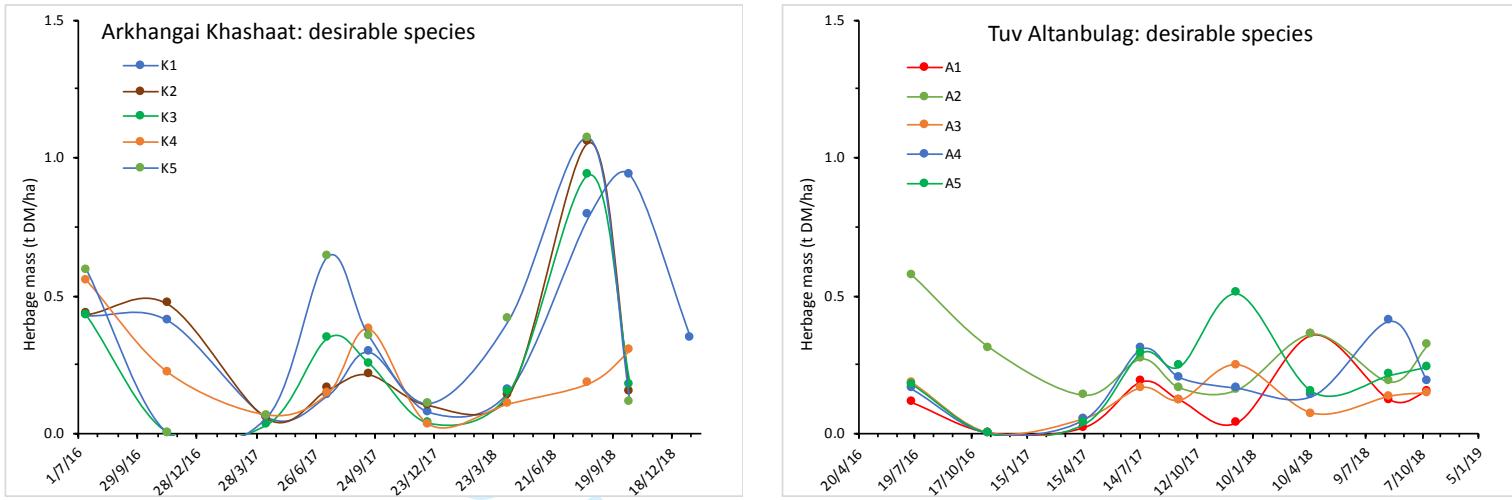

648

649 
650 Fig. 4. Total sheep equivalents for all livestock species in Khashaat and Altanbulag from 1970-2019

651 (adapted from MONSIS data). Dzuds occurred in 1977, 1983 \& 1985, 2000-2001 \& 2010.

652
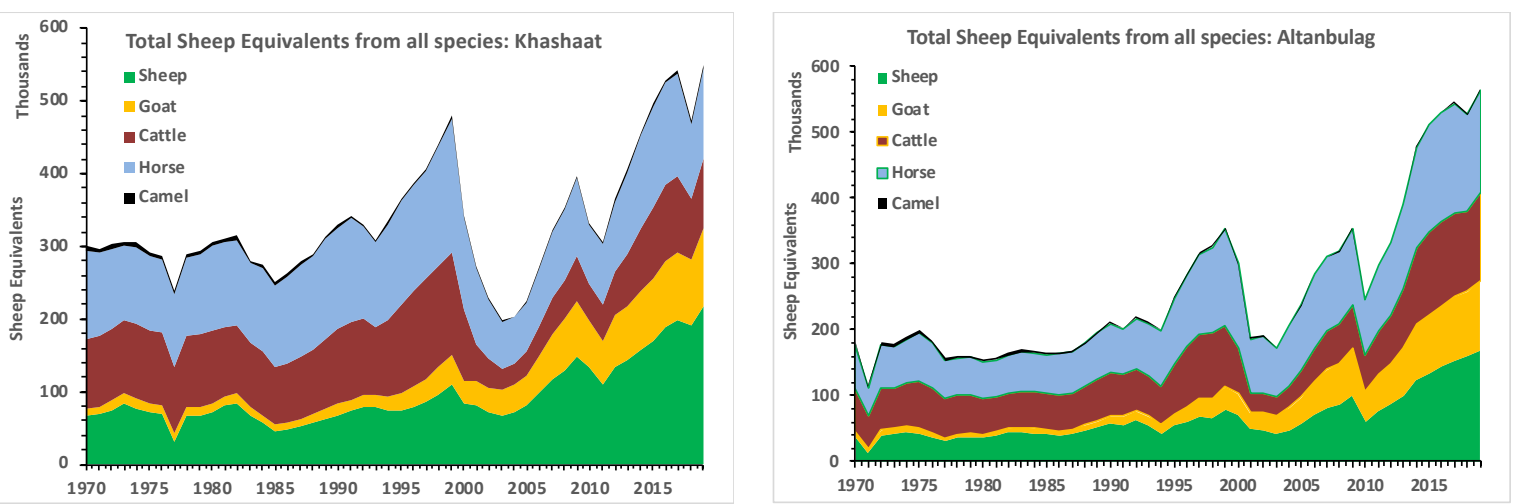

653

654 
655 Fig. 5. Average total sheep equivalents (sheep, goats, cattle \& horses) and average stocking rates 656 for the herders surveyed in Khashaat and in Altanbulag from spring 2017 to winter 2018.

657
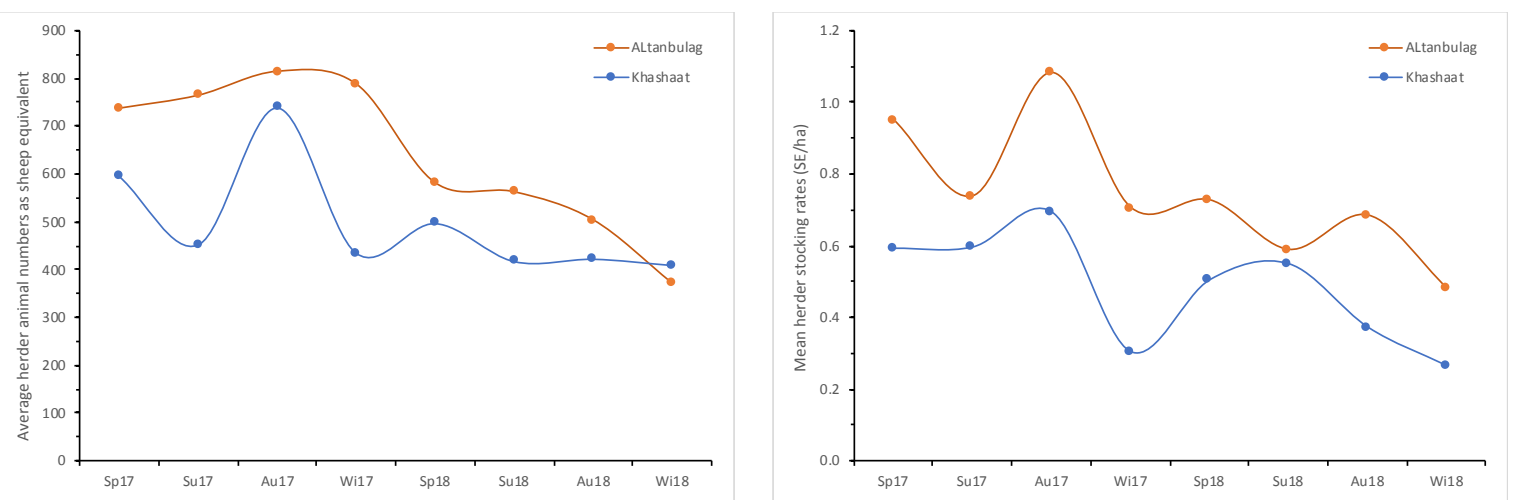

658

659 
660 Fig. 6. Sheep, goat, cattle and horse liveweights with age in autumn 2017, Altanbulag herder (A5).

661 Peak annual liveweights were recorded in autumn, except for horses where more data was collected 662 in spring.

663
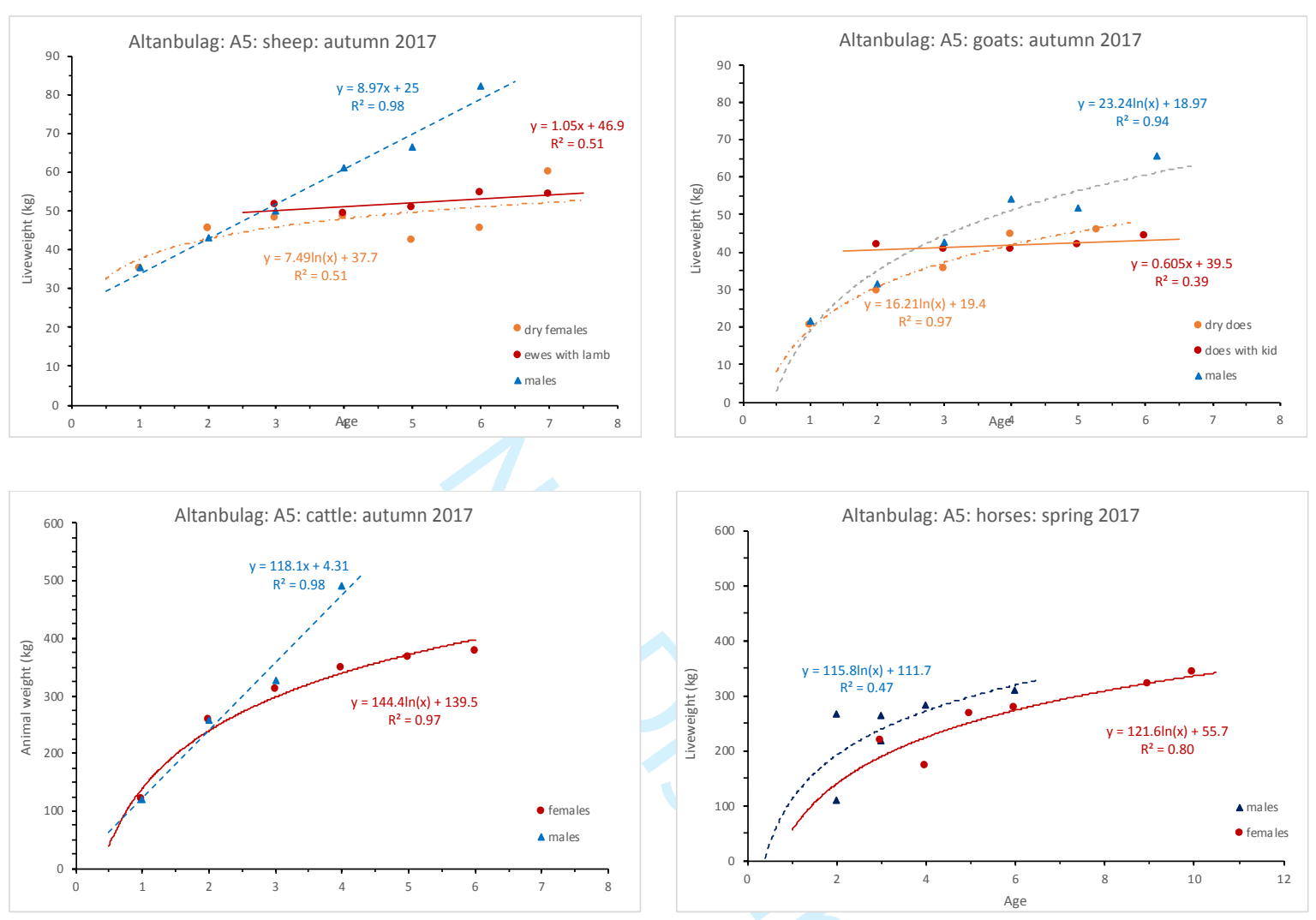

664

665 
666 Fig. 7. Relationship between liveweights in autumn 2017 (late September or early December) and 667 liveweight in spring 2018 (late April) for sheep \& goats, and cattle \& horses for the five herder 668 households in Altanbulag. Only four had cattle and horses.

669
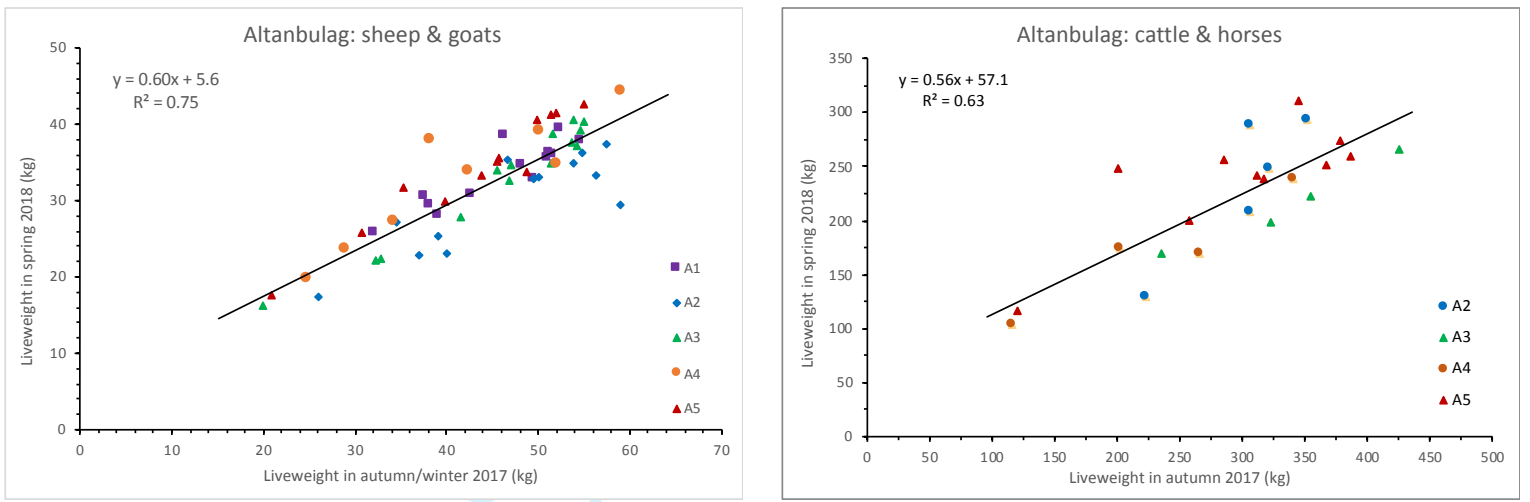

670

671 
Mongolia has seen a doubling in livestock numbers since 1990, which has resulted in significant grassland degradation, and accentuated the poor livestock productivity. This paper examines the size, structure and efficiency of Mongolian flocks and herds using a survey of herders in central Mongolia. The efficiency of livestock production is much lower than could be possible on these degraded grasslands. Ways of reducing animal numbers on the grassland and improving productivity are discussed. 


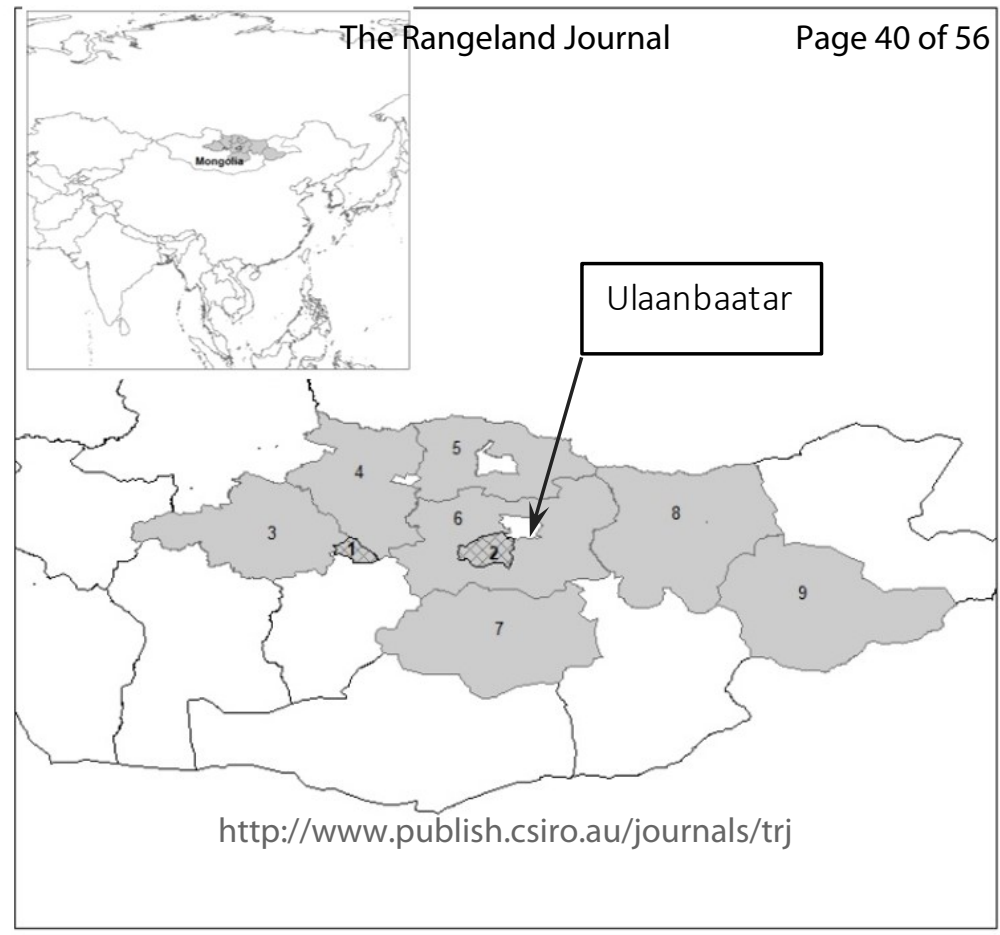




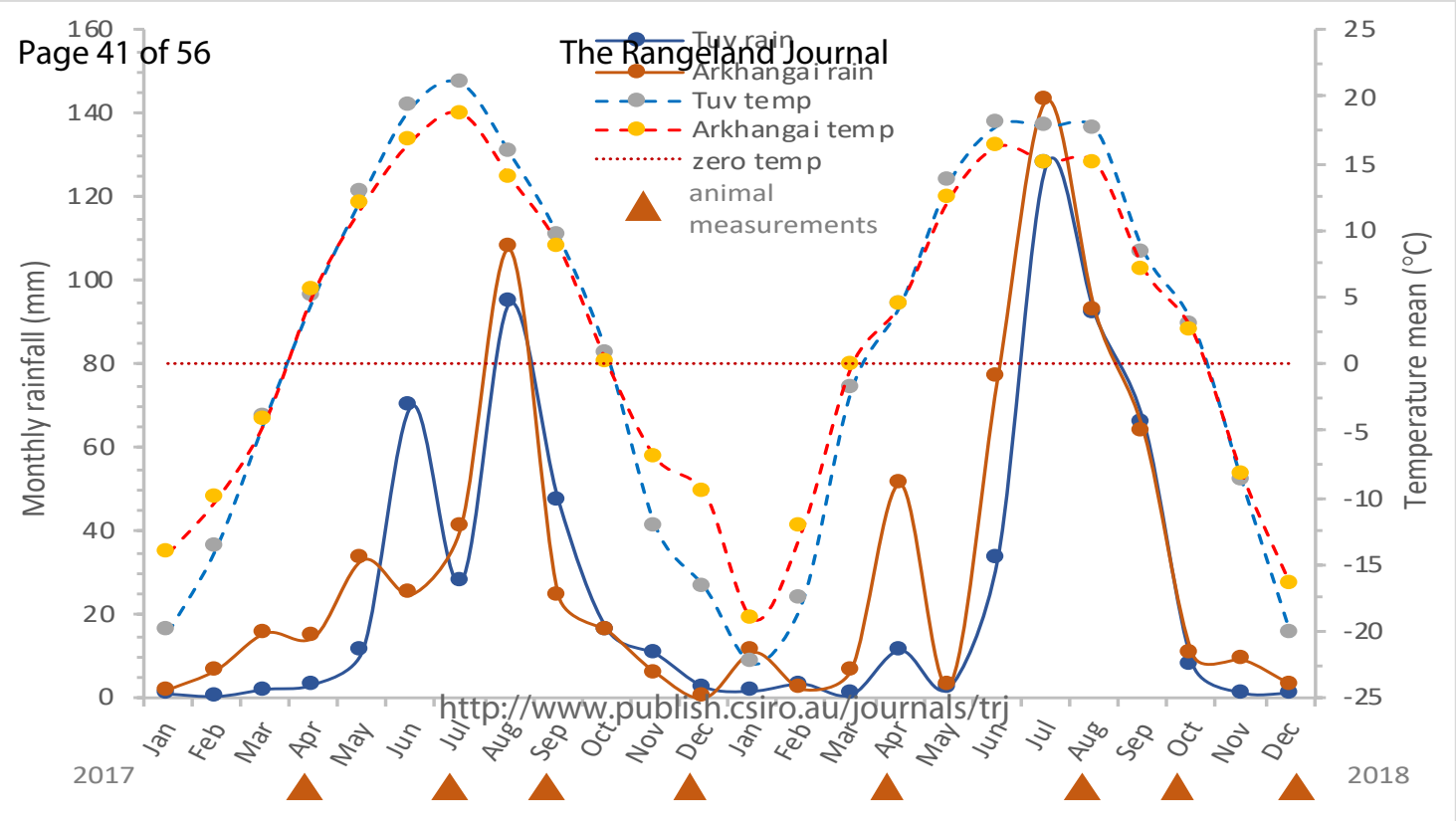




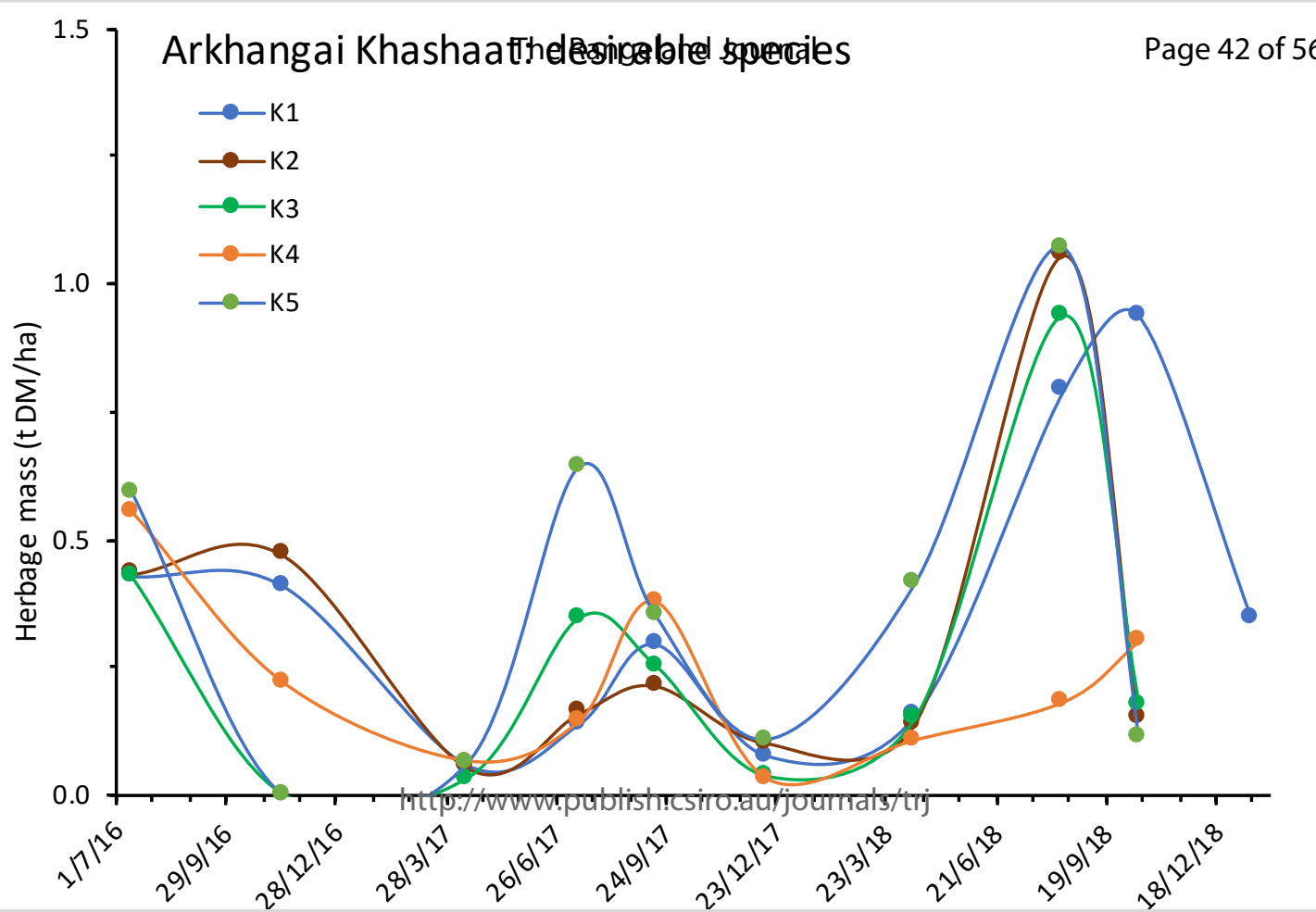




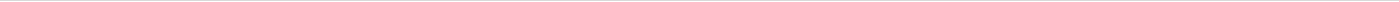




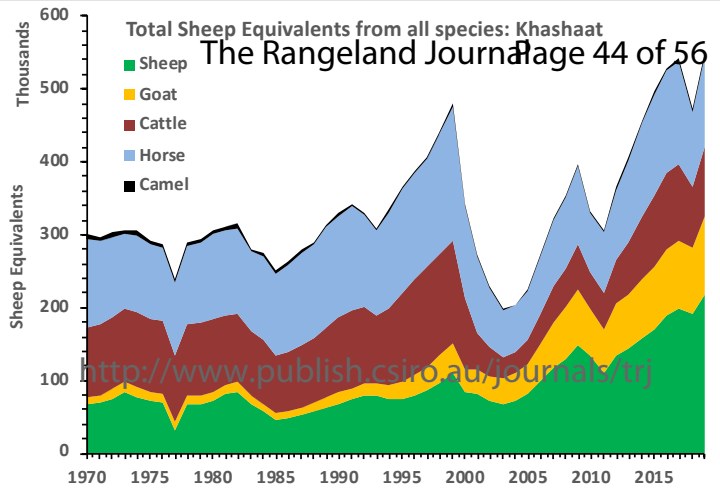




\section{The Rangeland Journfllage 46 of 56}

http://www.publish.csiro.au/journals/trj 
Page 47 of 56 he Rangeland Journal

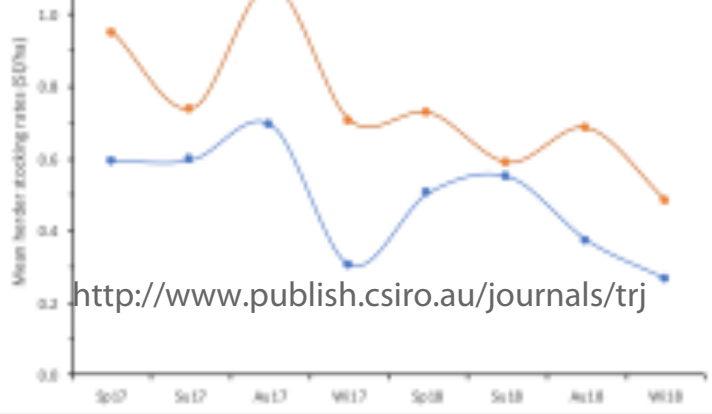




\section{Altanbulag: A5:ThąRangelandteqrinal2017}

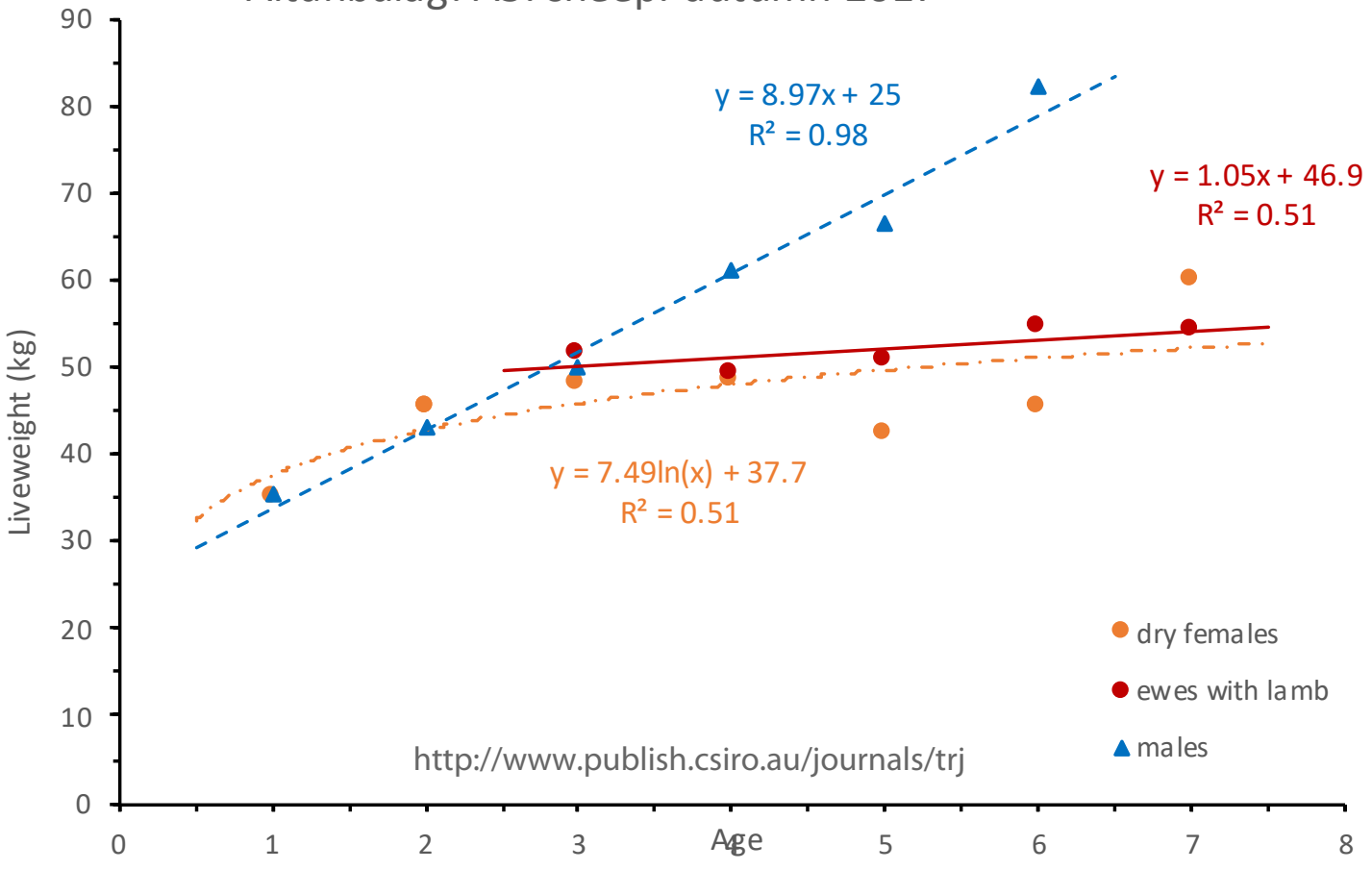




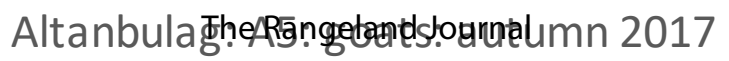

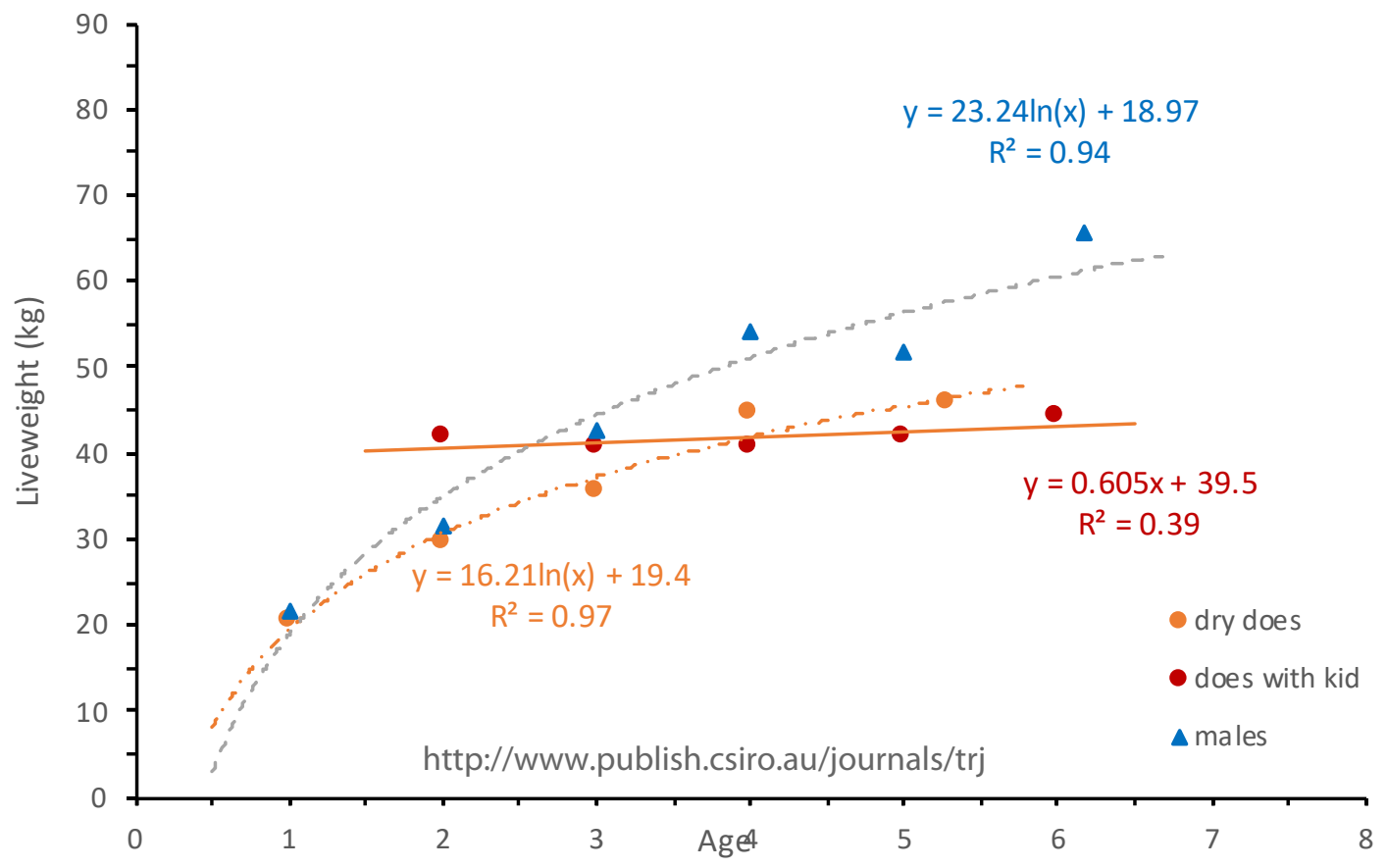




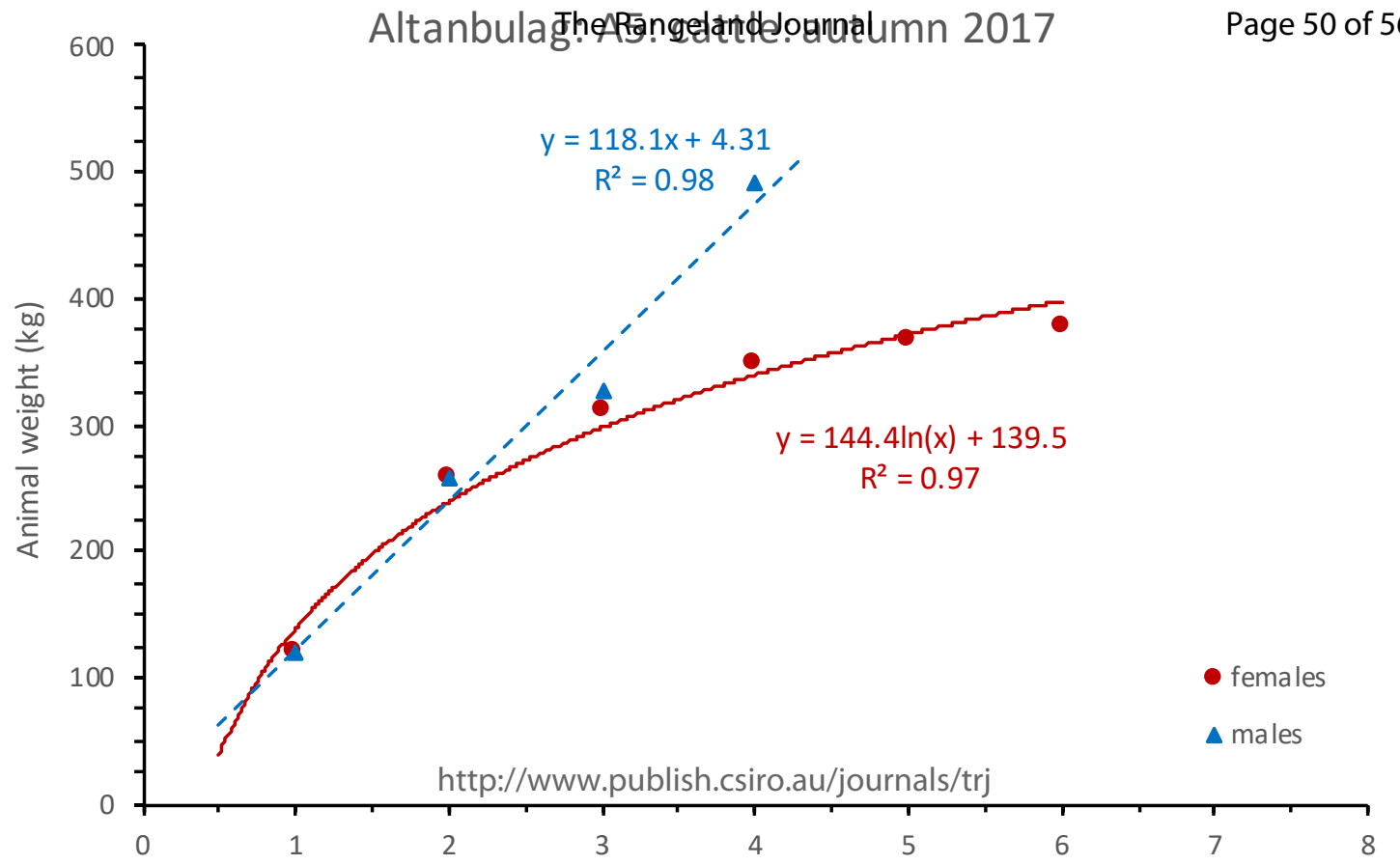


Page 51 of 56

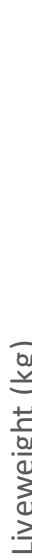

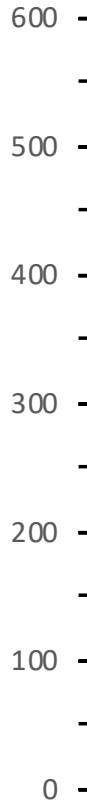

0

Altanbulathe Aänglabngegurnglring 2017 


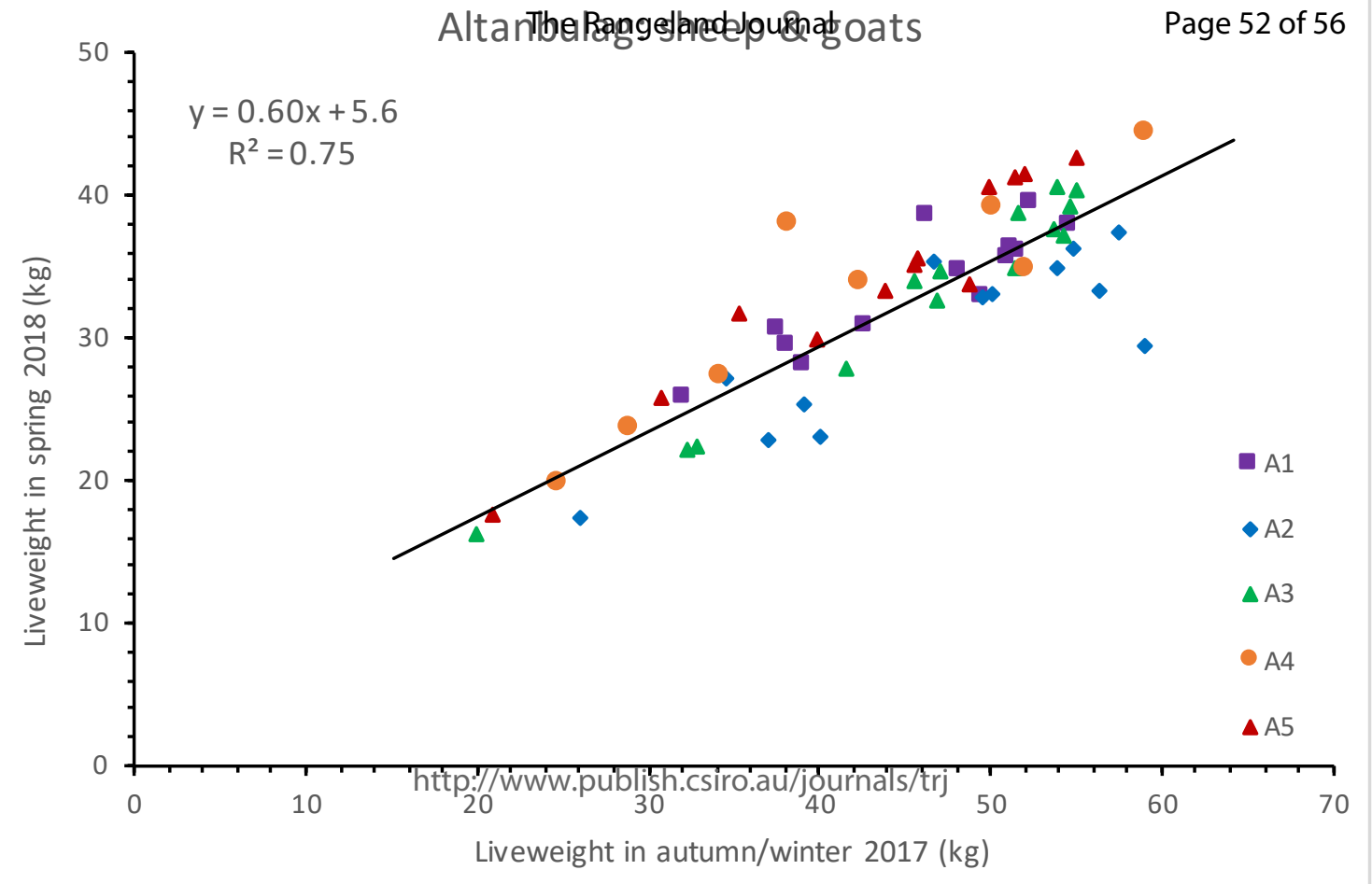


Page 53 of 56

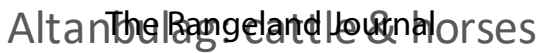

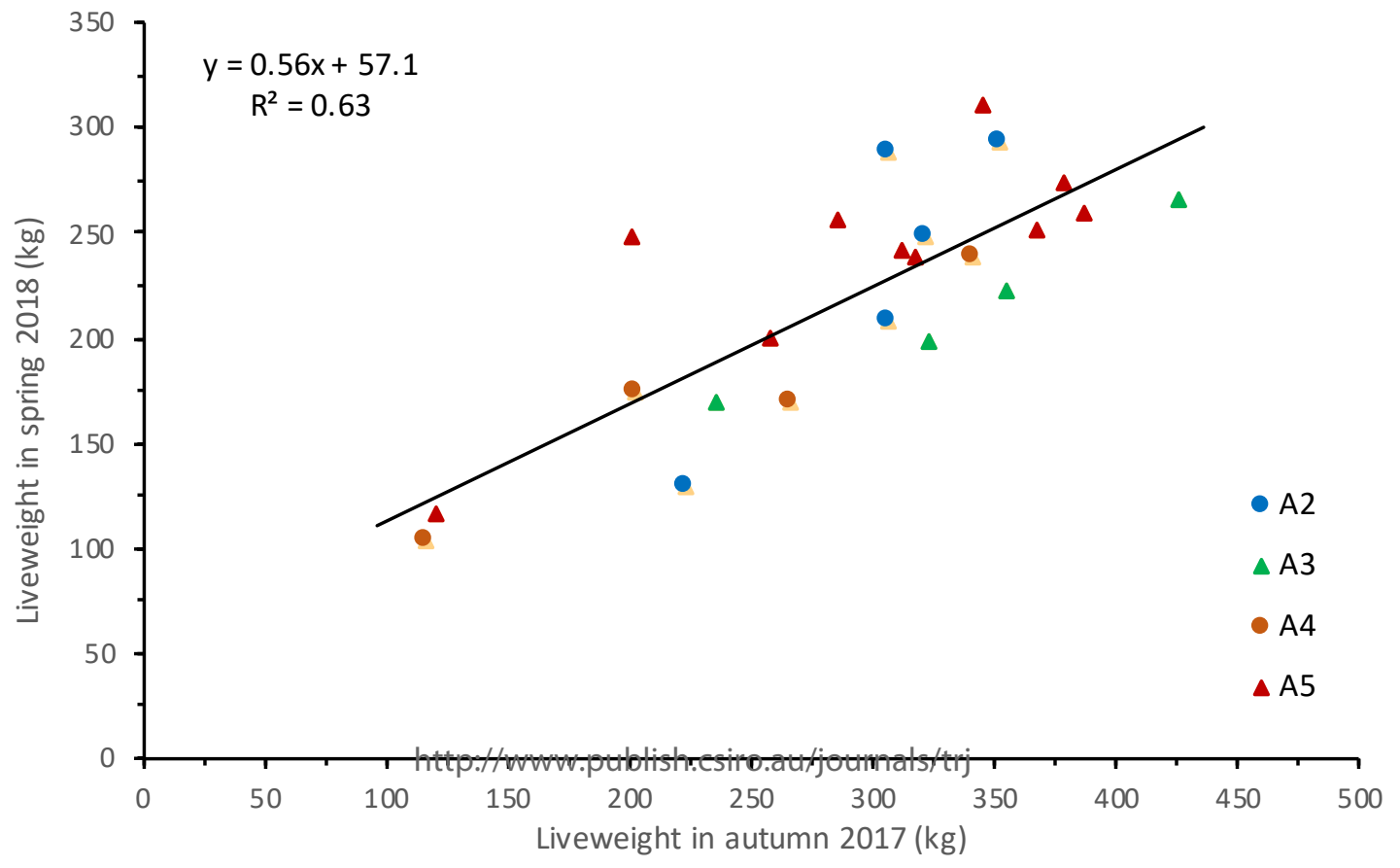


Table 1. Mean livestock numbers over summer and winter in $2017 / 2018$ for the ten herders surveyed and total sheep equivalents (SE) and estimated grazing area in each season.

\begin{tabular}{|c|c|c|c|c|c|c|c|c|c|c|c|c|c|}
\hline & \multirow{2}{*}{$\begin{array}{l}\text { Soum } \\
\text { Herder }\end{array}$} & \multicolumn{5}{|c|}{ Khashaat } & \multicolumn{5}{|c|}{ Altanbulag } & \multirow{2}{*}{$\begin{array}{c}\text { Khashaat } \\
\text { Mean }\end{array}$} & \multirow{2}{*}{$\begin{array}{c}\text { Altanbula } \\
\text { g } \\
\text { Mean }\end{array}$} \\
\hline & & $\mathrm{K} 1$ & K2 & K3 & K4 & K5 & A1 & $\mathrm{A} 2$ & A3 & A4 & A5 & & \\
\hline \multirow{3}{*}{$\begin{array}{l}\text { Sheep } \\
\text { (No.) }\end{array}$} & Summe & 128 & 275 & 241 & 266 & 312 & 338 & 46 & 340 & 454 & 326 & 244 & 301 \\
\hline & & & & & & & & & & & & & \\
\hline & Winter & 118 & 185 & 217 & 234 & 378 & 373 & 53 & 369 & 306 & 346 & 226 & 289 \\
\hline \multirow{3}{*}{$\begin{array}{l}\text { Goats } \\
\text { (No.) }\end{array}$} & Summe & 115 & 164 & 98 & 255 & 110 & 218 & 72 & 221 & 366 & 389 & 148 & 253 \\
\hline & & & & & & & & & & & & & \\
\hline & Winter & 109 & 146 & 89 & 201 & 133 & 240 & 80 & 207 & 278 & 410 & 135 & 243 \\
\hline \multirow{3}{*}{$\begin{array}{l}\text { Cattle } \\
\text { (No.) }\end{array}$} & Summe & 16 & 218 & 37 & 24 & 27 & 29 & 10 & 28 & 59 & 48 & 64 & 35 \\
\hline & & & & & & & & & & & & & \\
\hline & Winter & 12 & 181 & 40 & 21 & 35 & 33 & 12 & 40 & 44 & 52 & 58 & 36 \\
\hline \multirow{3}{*}{$\begin{array}{l}\text { Horses } \\
\text { (No.) }\end{array}$} & Summe & - & 4 & 4 & - & 11 & - & 10 & - & - & 9 & 6 & 10 \\
\hline & & & & - & & & & & & & & & \\
\hline & Winter & - & 4 & 5 & - & 11 & - & 9 & - & 24 & 9 & 7 & 14 \\
\hline \multirow{3}{*}{$\begin{array}{l}\text { Total } \\
\text { Number }\end{array}$} & Summe & 253 & 661 & 380 & 545 & 657 & 585 & 136 & 589 & 879 & 773 & 499 & 592 \\
\hline & & & & & & & & & & & & & \\
\hline & Winter & 239 & 515 & 351 & 456 & 686 & 634 & 151 & 616 & 633 & 821 & 449 & 571 \\
\hline \multirow{3}{*}{ Total SE } & Summe & 258 & 504 & 494 & 550 & 526 & 688 & 195 & 644 & 1008 & 862 & 466 & 679 \\
\hline & $r$ & & & & & & & & & & & & \\
\hline & Winter & 236 & 327 & 361 & 365 & 492 & 562 & 168 & 627 & 664 & 827 & 356 & 570 \\
\hline \multirow{5}{*}{$\begin{array}{l}\text { Grazing } \\
\text { area (ha) }\end{array}$} & Spring & - & - & - & - & 800 & 1000 & 800 & 900 & 700 & 600 & 960 & 800 \\
\hline & Summe & 900 & 1200 & 900 & 1000 & 500 & 700 & 600 & 1200 & 3000 & 700 & 500 & 1240 \\
\hline & & & & & & & & & & & & & \\
\hline & Autumn & - & 1000 & - & - & 600 & 600 & 900 & 700 & 800 & 800 & 1850 & 760 \\
\hline & Winter & 700 & 900 & 3000 & 2800 & 2500 & 4800 & 400 & 2100 & 600 & 2500 & 1367 & 2080 \\
\hline
\end{tabular}


Table 1. Average numbers of livestock, weaning rates and percent males for the ten herders surveyed in Khashaat and Altanbulag Soums. Data are for the maximum number recorded in a spring, summer or autumn 2017 measurement. The totals include animals whose age not recorded.

\begin{tabular}{|c|c|c|c|c|c|c|c|c|c|}
\hline \multirow{2}{*}{$\begin{array}{c}\text { livestoc } \\
k\end{array}$} & \multicolumn{3}{|c|}{ females } & \multicolumn{3}{|c|}{ males } & \multirow{2}{*}{$\begin{array}{l}\text { young } \\
\text { / year }\end{array}$} & \multirow{2}{*}{$\begin{array}{c}\text { weanin } \\
\text { g } \\
\%\end{array}$} & \multirow{2}{*}{$\begin{array}{c}\text { male: } \\
\text { female } \\
\%> \\
2 y r s\end{array}$} \\
\hline & & $\begin{array}{l}>2 \\
\text { yrs }\end{array}$ & total & $\begin{array}{l}1-2 \\
\text { yrs }\end{array}$ & $\begin{array}{l}>2 \\
\text { yrs }\end{array}$ & total & & & \\
\hline sheep & 50 & 115 & 184 & 59 & 73 & 139 & 55 & $48 \%$ & $63 \%$ \\
\hline goats & 41 & 79 & 133 & 32 & 57 & 102 & 37 & $46 \%$ & $72 \%$ \\
\hline cattle & 11 & 23 & 32 & 10 & 6 & 15 & 10 & $46 \%$ & $27 \%$ \\
\hline horses & 2 & 5 & 8 & 2 & 6 & 9 & 2 & $43 \%$ & $106 \%$ \\
\hline
\end{tabular}


Table 1. Mongolian Sheep Head Indices, compared to the mean range in 50kg Sheep Equivalents (SE) from animal weights.

\begin{tabular}{|l|c|c|}
\hline Livestock & $\begin{array}{c}\text { Sheep } \\
\text { Head Index }\end{array}$ & $\begin{array}{c}\text { Sheep Equivalent } \\
\text { (50kg) } \\
\text { from weights }\end{array}$ \\
\hline Sheep & 1 & $0.7-0.9$ \\
Goat & 0.9 & $0.6-0.8$ \\
Cattle & 6 & $3.9-5.2$ \\
Horse & 7 & $4.4-6.1$ \\
Camel & 5 & \\
\hline
\end{tabular}

